\title{
OPTIMASI PSO UNTUK METODE CLUSTERING FUZZY C-MEANS DALAM PENGELOMPOKAN KELAS
}

\author{
Max Teja Ajie Cipta Widiyanto \\ Teknik Informatika Sekolah Tinggi Teknik PLN Jakarta \\ max@sttpln.ac.id
}

\begin{abstract}
Abstrak
Clustering is a method that divides data objects into groups based on information found in data describing objects and relationships between them. In partition-based cluster analysts K-Means method and Fuzzy CMeans Method which is a frequent and commonly used clustering method. However, in its development now with various macar data with the complexity of the variable would be more asked again to the effectiveness and as efficiently whether the method can cluster the data. So it is necessary to optimize where the method has a weakness that is likely to mask the impact of the deficiency in clustering a data object that has a complex variable. Data data used is the value of slot shift one with a variable of the value Academic, nonacademic value in the form of a questionnaire value attitudes assessed by each teacher will be inputted, as a determinant of the division of leading classes in the future in the next teaching. In this study tried to correct some of the deficiencies of the Fuzzy C-Means algorithm ie the selection of early cluster centers and local solutions. An efficient algorithm is proposed to improve the grouping of such methods with Particle Swarm Optimization. In recent years, Particle Swarm Optimization (PSO) has been successfully applied to a number of real-world grouping issues with fast and effective convergence for high-dimensional data.
\end{abstract}

\begin{abstract}
Clustering adalah metode yang membagi objek data ke dalam kelompok berdasarkan informasi yang ditemukan dalam data yang menggambarkan objek dan hubungan di antara mereka. Dalam analis cluster berbasis partisi metode K-Means dan Metode Fuzzy C-Means yang merupakan metode clustering yang sering dan lazim banyak digunakan. Akan tetapi dalam perkembanganya sekarang dengan berbagai macar data dengan kompleksitas variabel tentunya akan lebih ditanyakan lagi ke efektifitas dan seefisien apakah metode tersebut dapat mengcluster data tersebut. Maka itu perlu adanya Optimasi dimana metode tersebut memiliki kelemahan yang kemungkinan akan menutupi dampak kekurangan tersebut di dalam mengcluster suatu objek data yang punya variabel kompleks. Objek data yang dipakai adalah nilai rapot semeser satu dengan variabel dari nilai Akademis, Nilai non akademis yang berupa nilai kuosioner sikap yang dinilai dari tiap guru akan di inputkan, sebagai penentu pembagian kelas unggulan kedepannya dalam ajaran berikutnya. Dalam penelitian ini mencoba untuk memperbaiki beberapa kekurangan dari algoritma Fuzzy C-Means yaitu pemilihan pusat cluster awal dan solusi lokal. Algoritma yang efisien diusulkan untuk meningkatkan pengelompokan metode tersebut dengan Particle Swarm Optimization. Dalam beberapa tahun terakhir, Particle Swarm Optimization (PSO) telah berhasil diterapkan untuk sejumlah masalah pengelompokan dunia nyata dengan konvergensi cepat dan efektif untuk data dimensi tinggi.
\end{abstract}

Kata kunci : Fuzzy C-Means, pengelompokan kelas, Optimasi PSO, Raport, Nilai Sikap

\section{PENDAHULUAN}

Pendidikan merupakan salah satu faktor kemajuan dan kemandirian bangsa. Semakin maju pendidikan suatu bangsa, maka akan semakin maju dan mandiri bangsa tersebut. Melalui pendidikan para generasi penerus bangsa dibentuk kualitasnya. Pendidikan nasional berfungsi mengembangkan kemampuan dan membentuk watak serta peradaban bangsa yang bermartabat dalam rangka mencerdaskan kehidupan bangsa, bertujuan untuk mengembangkan potensi peserta didik agar menjadi manusia yang beriman dan bertakwa kepada Tuhan Yang Maha Esa, berakhlaq mulia, sehat, berilmu, cakap, kreatif, mandiri dan menjadi warga negara yang demokratis serta bertanggung jawab [1]. Berdasarkan tujuan pendidikan tersebut maka kualitas dan manajemen pembelajaran di sekolah atau lembaga pendidikan perlu ditingkatkan. Salah satu indikator kualitas dan manajemen sekolah atau lembaga pendidikan dapat dilihat dari prestasi belajar siswa.

Jika lingkungan belajar memberikan pengaruhi positif kepada siswa, maka sikap yang terbentuk pada diri siswa ialah sikap belajar yang baik, yaitu siswa merasa senang dalam mengikuti proses pembelajaran yang dikelola oleh guru di kelas. Sebaliknya jika semua faktor tersebut memberikan pengaruhi negatif kepada siswa, maka sikap yang terbentuk pada diri siswa ialah sikap belajar yang tidak baik yaitu siswa merasa tidak senang dalam mengikuti pembelajaran yang dikelola guru di kelas.

Proses belajar di sekolah adalah proses yang sifatnya kompleks dan menyeluruh. Banyak orang yang berpendapat bahwa untuk meraih prestasi yang tinggi dalam belajar, selain harus mempunyai 
sikap positif seseorang harus juga memiliki Intelligence Quotient (IQ) yang tinggi, karena inteligensi merupakan bekal potensial yang akan memudahkan dalam belajar dan pada gilirannya akan menghasilkan prestasi belajar yang lebih baik. Menurut Anastasi dan Urbina hakikat inteligensi adalah kemampuan untuk menetapkan dan mempertahankan suatu tujuan, untuk mengadakan penyesuaian dalam rangka mencapai tujuan itu, dan untuk menilai keadaan diri secara kritis dan objektif[1].

Memang harus diakui bahwa mereka yang memiliki intelegensi rendah dan mengalami keterbelakangan mental akan mengalami kesulitan, bahkan mungkin tidak mampu mengikuti pendidikan formal yang seharusnya sesuai dengan usia mereka. Namun fenomena yang ada menunjukkan bahwa tidak sedikit orang dengan intelegensi tinggi yang berprestasi rendah, dan ada banyak orang dengan intelegensi sedang yang dapat mengungguli prestasi belajar orang dengan intelegensi tinggi.

Anak yang memiliki kemampuan unggul merupakan aset nasional dan Undang-Undang Sistem Pendidikan Nasional menekankan agar kepada mereka diberikan perhatian khusus agar dapat dimanfaatkan untuk pembangunan Indonesia [5]. Anak cerdas dan berbakat istimewa memiliki penyesuaian emosional lebih bagus dari pada anak normal[4]. Benbow dan Lubinski mengatakan bahwa siswa yang memiliki kemampuan dan mempunyai motivasi tinggi, akan lebih cepat memperoleh pengetahuan dan keterampilan dalam mengikuti program akselerasi (unggulan) [5]. Ormrod mengatakan bahwa siswa cerdas dan berbakat istimewa memiliki motivasi yang tinggi ketika menghadapi tugas-tugas yang menantang, mereka juga memiliki konsep diri akademik positif, memiliki fleksibilitas dalam berfikir, dan sangat fleksibel menggunakan pendekatan dalam belajar [6]. Pada pasal 5 ayat (1) Undang-Undang nomor 20 tahun 2003 dinyatakan warga negara yang memiliki potensi kecerdasan dan bakat istimewa berhak untuk memperoleh pendidikan khusus. Selanjutnya pada pasal 12 ayat (b) disebutkan bahwa Setiap peserta didik pada setiapsatuan pendidikan berhak mendapat pelayanan pendidikan sesuai dengan bakat, minat dan kemampuannya [2].

Atas dasar itulah di SMK Askhabul Kahfi menginginkan pengelompokan yang lebih baik dari pengelompokan kelas yang sudah ada sebelumya, yang biasanya dilakukan di sekolah ini dan sekolah - sekolah lain pada umumnya hanya membagi kelas secara acak, atau pengelompokan sesuai pendaftaran masuk saja. Ini memungkinkan potesi kecerdasan anak, minat serta karakter anak belum bisa dikembangkan secara optimal.

Meskipun demikian pengelompokan yang lebih modern sekalipun yag sudah pernah ada hanya membagi kelas menurut nilai akademis saja itu dirasa kurang objektif dan terkesan homogen tampa mengindahkan kemampuan atau minat siswa yang lain serta yang terpenting adalah perilaku atau sikap anak di lingkungan sekolah maupun pada saat kegiatan belajar mengajar. Maka di penelitian ini penulis akan mencoba meneliti pembagian kelas sesuai dengan kebutuhan kondisi kelas yaitu menjadi 3 kelas dengan variabel akademis yang terdiri dari 24 variabel dan nilai perilaku atau sikap dengan 5 variabel yang diharapkan bisa membentuk kelas yang ideal untuk pembelajaran dan bisa menentukan jenis pendekatan belajar yang sesuai.

Pengelompokan disini penulis akan memakai metode clustering, yaitu metode yang membagi objek data ke dalam kelompok berdasarkan informasi yang ditemukan dalam data yang menggambarkan objek dan hubungan di antara mereka. Ada berbagai algoritma telah dikembangkan dalam beberapa tahun terakhir untuk memecahkan masalah clustering data. Algoritma pengelompokan data dapat berupa hirarkis atau partisi.

Metode yang sering diusulkan dalam beberapa penelitian sebelmnya adalah K-Means, algoritma partisi berikut memiliki beberapa kekurangan yaitu jumlah cluster $\mathrm{K}$ harus diketahui dalam lanjutan, itu sensitif terhadap pilihan acak dari pusat klaster awal, dan itu adalah sensitif terhadap outlier[10]. Dalam tulisan ini, kami mencoba untuk memperbaiki beberapa kekurangan dari algoritma Fuzzy C-Means dan algoritma yang efisien diusulkan untuk meningkatkan pengelompokan FCM dengan Particle Swarm Optimization. Dalam beberapa tahun terakhir, Particle Swarm Optimization (PSO) telah berhasil diterapkan untuk sejumlah masalah pengelompokan dunia nyata dengan konvergensi cepat dan efektif untuk data dimensi tinggi [7].

Sekalipun Fuzzy C-Means tergolong algoritma yang efektif untuk untuk melakukan pengklusteran namun pemilihan acak atas titik pusat kluster seringkali membuat proses perulangan dengan mudah terjebak dalam titik optimal lokal (local optimal solution)[9]. Kelemahan ini yang mendorong penggabungan Fuzzy C-means dengan revolutionary algorithm semacam Algoritma Genetika, Simulated Annealing (SA), Ant Colony Optimization (ACO) dan Particle Swarm Optimization (PSO) untuk mendapatkan hasil terbaik[10].

Dari penjelasan di atas maka penulis berharap penelitian ini dapat merealisasikan suatu metode yang dapat menggabungkan keunggulan dari metode pengklusteran Fuzzy C-Means (FCM) dan algoritma optimalisasi Particle Swarm Optimization (PSO) sehingga dapat mengatasi kelemahan dari metode pengklusteran Fuzzy C-Means (FCM) selama ini yaitu terjebak dalam titik lokal optimal. yang penulis ajukan sebagai bahan penelitian diharapkan dapat memberikan hasil yang pengklusteran yang lebih baik daripada metode Fuzzy C-Means (FCM) tradisional.

Kriteria kelas yang ideal pada suatu clustering yang diukur dengan validitas fuzzy clustering eksternal dikarenakan di penilitian ini menggunakan pengelompokan fuzzy dan clustering merupakan metode unsupervised learning yaitu pembelajaran tidak terbimbing pengelompokan data berdasar kemiripan/ketidakmiripan antar data tampa ada label kelas yang diketahui sehingga dalam penilaian kebagusan cluster tampa membutuhkan informasi eksternal. 


\section{DASAR TEORI}

\subsection{Metode Pengelompokan}

Dalam analisis klaster, terdapat banyak metode untuk mengelompokkan observasi ke dalam klaster. Secara umum metode pengelompokan dalam analisis klaster dibedakan menjadi metode hirarki (Hierarchical Clustering Method) dan metode non hirarki (Nonhierarchical Clustering Method) atau berbasis partisi. Metode hirarkidigunakan apabila belum ada informasi jumlah klaster yang dipilih. Sedangkanmetode non hirarki bertujuan untuk mengelompokkan objek ke dalam klaster $(n)$, di mana nilai telah ditentukan sebelumnya [13].

\subsection{Ukuran Jarak}

Dalam hal ini, ukuran jarak digunakan untuk menempatkan observasi ke dalam klaster berdasarkan centroid terdekat. Ukuran jarak yang digunakan dalam metode K-Means maupun Fuzzy C-Means diantaranya adalah :

1). Euclidean distance

Formula jarak antar dua titik dalam satu, dua dan tiga dimensi secara berurutan ditunjukkan pada formula 1,2 , berikut ini :

$$
\begin{aligned}
& d(p, q)=\sqrt{(p 1-q 1)^{2}+(p 2-q 2)^{2}} \\
& d(p, q)=\sqrt{(p 1-q 1)^{2}+(p 2-q 2)^{2}+(p 3-q 3)^{2}}
\end{aligned}
$$

\subsection{Fuzzy Cluster Means (FCM)}

Pada proses pengklasteran (clustering) secara klasik (misalnya pada algoritma Clustering KMeans), pembentukan partisi dilakukan sedemikian rupa sehingga setiap obyek berada tepat pada satu partisi. Namun, adakalanya tidak dapat menempatkan suatu obyek tepat pada suatu partisi, karena sebenarnya obyek tersebut terletak di antara 2 atau lebih partisi yang lain. Pada logika fuzzy, metode yang dapat digunakan untuk melakukan pengelompokan sejumlah data dikenal dengan nama fuzzy clustering. Fuzzy clustering lebih alami jika dibandingkan dengan pengklasteran secara klasik. Suatu algoritma clustering dikatakan sebagai fuzzy clustering jika algoritma tersebut menggunakan parameter strategi adaptasi secara soft competitive. Sebagian besar algoritma fuzzy clustering didasarkan atas optimasi fungsi obyektif atau modifikasi dari fungsi obyektif tersebut[10].

Salah satu teknik fuzzy clustering adalah FCM. Yakni suatu teknik pengklasteran data yang keberadaan tiap-tiap data dalam suatu cluster ditentukan oleh nilai/derajat keanggotaan tertentu. Teknik ini pertama kali diperkenalkan oleh J. Dunn [1] yang selanjutnya digeneralisasi oleh Jim Bezdek pada tahun 1981 [2].

FCM adalah suatu teknik klasifikasi data dimana keberadaan tiap-tiap titik data dalamsuatu cluster ditentukan oleh derajat keanggotaan. FCM merupakan algoritma clustering yang terawasi, karena pada algoritma FCM jumlah cluster yang akan dibentuk perlu ditentukan terlebih dulu. Konsep dasar FCM adalah menentukan pusat kelompok yang akan menandai lokasi rata-rata untuk tiap-tiap cluster. Pada kondisi awal, pusat cluster masih belum akurat.Tiap-tiap data memiliki derajat keanggotaan pada tiap-tiap cluster. Dengan cara memperbaiki pusat cluster dan derajat keanggotaan tiap-tiap data secara berulang-ulang, maka didapatlokasi pusat cluster optimal. Perulangan ini didasarkan pada fungsi obyektif yang menggambarkan jarak dari titik data yang diberikan ke pusat cluster yang terbobot olehderajat keanggotaan titik data tersebut [12].Fungsi obyektif yang digunakan FCM adalah [11]:

Fuzzy Cluster Means (FCM) merupakan algoritma yang digunakan untuk melakukan clustering data berdasarkan keberadaan tiap-tiap titik data sesuai dengan derajat keanggotaannya [15]. Berikut ini adalah algoritma clustering FCM [4] :

1. Input data yang akan di-cluster $X$, berupa matrik berukuran $n \times m$ ( $n=$ jumlah sample data, $m=$ atribut setiap data), dimana Xij adalah data sample $k e-i(i=1,2,3, \ldots, n)$, atribut ke-j $(j=1,2, . ., m)$.

2. Selanjutnya, tentukan nilai-nilai awal perhitungan seperti,j umlah cluster, pangkat, iterasi maksimal, eror terkecil yang diharapkan (I), fungsi objektif awal dan iterasiawalnya.

3. Bangkitkan nilai random dalam bentuk elemen matrik spartisi awal $U$ ( $\mu \mathrm{ik}$, $\mathrm{i}=1,2, \ldots, \mathrm{n} ; \mathrm{k}=1,2, . ., \mathrm{c}), \quad$ kemudian hitunglah jumlah setiap kolom dengan persamaan sebagai berikut :

$\mathrm{Qi}=\sum_{k=1}^{c} \mu_{\mathrm{ik}}$

Selanjutnya tentukan nilai matrks partisi awal, dengan persamaan sebagai berikut :

$\mu_{i k}=\frac{\mu_{i k}}{Q i} \ldots$

4. Hitung pusat cluster ke-k; Vkj, dimana $\mathrm{k}=1,2, \ldots, \mathrm{c} ;$ danj $=1,2, \ldots, \mathrm{m}$, dengan persamaan sebagai berikut :

$v_{k j}=\frac{\sum_{i=1}^{n}\left(\left(\mu_{i k}\right)^{w} * X_{i j}\right)}{\sum_{i=1}^{n}\left(\mu_{i k}\right)^{w}}$

5. Selanjutnya, lakukan perhitungan nilai fungsi objektif pada iterasi ke-t $(\mathrm{Pt})$, dengan persamaan berikut :

$$
P_{t}=\sum_{i=1}^{n} \sum_{k=1}^{c}\left(\left[\sum_{j=1}^{m}\left(X_{i j} * \mathrm{~V}_{k j}\right)^{2}\right]\left(\mu_{i k}\right)^{w}\right) \ldots \ldots
$$

6. Hitung perubahan matriks partisi $U$, dengan persamaan sebagai berikut :

$$
\mu_{i k}=\frac{\left.\left[\sum_{j=1}^{m}\left(X_{i j}-V_{k j}\right)^{2}\right]^{\frac{-1}{w-1}} \ldots \ldots \ldots \ldots \ldots . . .6\right)}{\sum_{k=1}^{c}\left[\sum_{j=1}^{m}\left(X_{i j}-V_{k j}\right)^{2}\right]^{\frac{-1}{w-1}}}
$$

Dimana $\mathrm{i}=1,2, \ldots, \mathrm{n}$; dan $\mathrm{k}=1,2, \ldots, \mathrm{c}$;

7. Langkah terakhir adalah dengan mengecek kondisi berhenti, dengan ketentuan sebagai berikut :

a. Jika (|Pt $-\mathrm{Pt}-1 \mid<\mathfrak{I}$ atau (t > iterasi maksimal) maka berhenti

b. Jika tidak, maka $\mathrm{t}=\mathrm{t}+1$ kemudian ulangi langkah ke-4. 


\subsection{Algoritma Optimasi}

Dalam penelitian klastering ini, akan mencoba mengkombinasikan dan membandingkan Fuzzy CMeans dengan salah satu algoritma optimasi yang termasuk dalam Swarm Intelligence. Berikut ini penulis akan memaparkan beberapa algoritma optimasi yang populer yaitu : Genetic Algorithm (GA), Ant Colony Optimmization (ACO), Particle swarm optimization (PSO), Simulated Annaeling (SA). GA, SA masuk dalam kelompok evolutionary algorithm, sementara ACO dan PSO masuk dalam kategori swarm intelligence.

Evolutionary algorithm (EA) merupakan algoritma optimasi metaheuristic yang berdasar pada populasi secara umum. Cara kerja EA memanfaatkan mekanisme yang didasarkan evolusi biologis : mutasi, reproduksi, rekombinasi, seleksi. Kemudian Swarm intelligence [14] adalah kecerdasan kolektif yang muncul dari sekelompok agent atau individu makhluk hidup. Berikut ini beberapa contoh dan pengertian dari algoritma yang tergolong EA maupun Swarm intelligence.

1) Evolutionary Algorithm

a) Genetic Algorithm (GA) menurut Goldberg 1989 adalah algoritma pencarian berdasarkan seleksi alam dan genetika alam. Algoritma ini dipopulerkan awal tahun 1970-an oleh John Holland, namun beberapa ide yang mengarah pada metode ini sudah ada ditahun-tahun sebelumnya.

b) Simulated Annaeling (SA) adalah suatu algoritma optimasi yang mensimulasikan proses annaeling pada pembuatan materi yang terbuat dari butir kristal atau logam. Algoritma ini pertama kali dipaparkan oleh Scott Kirkpatrick tahun 1983dengan memanfaatkan persamaan boltzman.

2) Swarm Intelligence

a. Ant Collony Optimization (ACO) merupakan algoritma yang memanfaatkan banyaknya semut (ants) dalam menjelajahi ruang solusi dan menemukan area lokal yang produktif. Metode ini diusulkan oleh Marco Dorigo pada tesisnya tahun 1992.

b. Particle swarm optimization (PSO) termasuk dalam Swarm intelligence. Metode PSO dikembangkan pertama oleh Dr. Russel C. Eberhart dan Dr. James Kennedy pada tahun 1995. Tetapi, gagasan awal PSO ini dimulai oleh Beny dan Wang pada tahun 1989 dalam konteks robotika yang dinamakan Swarm Intelligence.Seperti yang telah dideskripsikan oleh Eberhart dan Kennedy, Algoritma PSO adalah sebuah populasi didasarkan proses pencarian stokastik, dimodelkan dari kebiasaan sosial sekumpulan burung[16].Tujuan dari PSO adalah menemukan posisi partikel dari hasil evaluasi paling terbaik yang diberikan oleh fungsi fitness (obyektif) [6]. PSO memanfaatkan suatu populasi individu untuk memeriksa ruang pencarian.

Dalam konteks ini, populasi dinamakan swarm dan individu dinamakan partikel. Kata partikel menunjukkan, misalnya, seekor burung dalam kawanan burung. Setiap individu atau partikel dalam PSO berhubungan dengan kecepatan (velocity). Partikel-partikel memiliki kecenderungan bergerak ke zona penelusuran yang paling baik dari semua penelusuran yang telah dilakukan. Pada algoritma PSO, perbaharui vektor kecepatan disetiap masing-masing partikel. Ada dua solusi yang mempengaruhi proses memperbaharui kecepatan, lakukan penyesuian posisi terbaik dari partikel (Particle best) dan penyesuaian terhadap partikel terbaik dari seluruh populasi (Global best).

PSO memiliki kemiripan dengan Genetic Algorithm (GA). Menurut Mathews [17] elemenelemen yang umum terdapat pada Genetic Algorithm (GA) dan Particle swarm optimization (PSO) adalah:

1. Keduanya menginisialisasi sebuah populasi dengan cara yang mirip.

2. Keduanya menggunakan fungsi evaluasi untuk menentukan seberapa bagus potential solusi tersebut.

3. Keduanya mengulang proses-proses yang sama dengan jumlah waktu yang telah ditentukan.

Namun terdapat perbedaan dengan GA, dimana PSO tidak mempunyai operator evolusi seperti crossover dan mutasi yang terdapat pada Genetic Algorithm (GA).

\subsection{Implementasi Particle Swarms Optimation (PSO)}

Misalkan kita mempunyai fungsi berikut :

$\min f(x)$

dimana $X(B) \leq X \leq X(A)$

dimana $X(B)$ adalah batas bawah dan $X(A)$ adalah batas atas dari $X$. Prosedur PSO dapat dijabarkan dengan langkah-langkah sebagai berikut [2]:

1. Asumsikan bahwa ukuran kelompok atau kawanan (jumlah partikel) adalah $N$. Untuk mengurangi jumlah evaluasi fungsi yang diperlukan untuk menemukan solusi, sebaiknya ukuran $N$ tidak terlalu besar, tetapi juga tidak terlalu kecil,agar ada banyak kemungkinan posisi menuju solusi terbaik atau optimal. Jika terlalu kecil, sedikit kemungkinan menemukan posisi partikel yang baik. Terlalu besar juga akan membuat perhitungan jadi panjang. Biasanya digunakan ukuran kawanan adalah 20 sampai 30 partikel.

2. Bangkitkan populasi awal $X$ dengan rentang $X(B)$ dan $X(A)$ secara random sehingga didapat $X 1, X 2, \ldots, X N$. Setelah itu, untuk mudahnya, partikel $j$ dan kecepatannya pada iterasi $i$ dinotasikan sebagai $X(I) j$ dan $V(I) j$ Sehingga partikel-partikel awal ini akan menjadi $X 1(0), X 2(0), \ldots, X N(0)$. Vektor $X j(0),(j$ $=1,2, \ldots, N$ disebut partikel atau vektor koordinat dari partikel. (seperti kromosom dalam algoritma genetika). Evaluasi nilai fungsi tujuan untuk setiap partikel dan nyatakan dengan :

$f[X 1(0)], f[X 2(0)], \ldots, f[X N(0)] \ldots \ldots \ldots(8)$ 
3. Hitung kecepatan dari semua partikel. Semua partikel bergerak menuju titik optimal dengan suatu kecepatan. Awalnya semua kecepatan dari partikel diasumsikan sama dengan nol. Set iterasi $i=1$.

4. Pada iterasi ke-i, temukan 2 parameter penting untuk setiap partikel $j$ yaitu:

(a) Nilai terbaik sejauh ini dari $X j(I)$ (koordinat partikel $j$ pada iterasi $l$ ) dan nyatakan sebagai Pbest,j, dengan nilai fungsi obyektif paling rendah (kasus minimasi), $f[X j(i)]$, yang ditemui sebuah partikel $j$ pada semua iterasi sebelumnya. Nilai terbaik untuk semua partikel $X j(I)$ yang ditemukan sampai iterasi ke-i, Gbest,dengan nilai fungsitujuan paling $\mathrm{kecil} /$ minimum diantara semua partikel untuk semuaiterasi sebelumnya, $f[X j(i)]$.

(b) Hitung kecepatan partikel $j$ pada iterasi ke $i$ dengan rumus sebagai berikut:

$$
\begin{aligned}
& \quad V j(i)=V j(i-1)+c 1 r 1[\text { Pbest }, j-x j(i-1)] \\
& +\ldots \ldots \ldots \ldots(9) \\
& c 2 r 2[\text { Gbest }-x j(i-1)], . j=1,2, \ldots, N
\end{aligned}
$$

dimana $c 1$ dan $c 2$ masing-masing adalah learning rates untuk kemampuan individu (cognitive) dan pengaruh sosial (group), dan $r 1$ dan $r 2$ bilangan random yang berdistribusi uniforml dalam interval 0 dan 1. Jadi parameters $c 1$ dan $c 2$ dmenunjukkan bobot dari memory (position) sebuah partikel terhadap memory (posisi) dari kelompok(swarm). Nilai dari $c 1$ dan $c 2$ biasanya adalah 2 sehingga perkalian $c 1 r 1$ dan $c 2 r 2$ memastikan bahwa partikel-partikel akan mendekati target sekitar setengah selisihnya.

(c) Hitung posisi atau koordinat partikel $j$ pada iterasi ke-i dengan cara

$X j(i)=X j(i-1)+V j(i) ; j=1,2, \ldots, N$.

Evaluasi nilai fungsi tujuan untuk setiap partikel dan nyatakan sebagai

$$
f[X 1(i)], f[X 2(I)], \ldots, f[X N(I)]
$$

5. Cek apakah solusi yang sekarang sudah konvergen. Jika posisi semua partikel menuju ke satu nilai yang sama, maka ini disebut konvergen. Jika belum konvergen maka langkah 4 diulang dengan memperbarui iterasi $i=i+1$, dengan cara menghitung nilai baru dari Pbest,j dan Gbest.Proses iterasi ini dilanjutkan sampai semua partikel menuju ke satu titik solusi yang sama. Biasanya akan ditentukan dengan kriteria penghentian (stopping criteria), misalnya jumlah selisih solusi sekarang dengan solusi sebelumnya sudah sangat kecil.

\subsection{PSO dengan Perbaikan}

Dalam implementasinya, ditemukan bahwa kecepatan partikel dalam PSO diupdate terlalu cepat dan nilai minimum fungsi tujuan sering terlewati. Karena itu ada revisi atau perbaikan terhadap algoritma PSO standard. Perbaikan itu berupa penambahan suatu inersia $\theta$ untuk mengurangi kecepatan. Biasanya nilai $\theta$ dibuat sedemikian hingga semakin meningkat iterasi yang dilalui, semakin mengecil kecepatan partikel. Nilai ini bervariasi secara linier dalam rentang 0.9 hingga 0.4. Secara matematis perbaikan ini bisa dituliskan.

$V j(i)=\theta V j(i-1)+c 1 r 1[$ Pbest,$j-X j(i-1)]+\ldots \ldots \ldots$ $c 2$ r2[Gbest-Xj(i-1)]; $j=1,2, \ldots, N$

Bobot inersia ini diusulkan oleh [3] untuk meredam kecepatan selama iterasi, yang memungkinkan kawanan burung menuju (konverge) titik target secara lebih akurat dan efisien dibandingkan dengan algoritma aslinya. Formula (9) adalah modifikasi terhadap formula (12). Nilai bobot inersia yang tinggi menambah porsi pencarian global (global exploration), sedangkan nilai yang rendah lebih menekankan pencarian lokal (local search). Untuk tidak terlalu menitikberatkan pada salah satu bagian dan tetap mencari area pencarian yang baru dalam ruang berdimensi tertentu, maka perlu dicari nilai bobot inersia $(\theta)$ yang secara imbang menjaga pencarian global dan lokal. Untuk mencapai itu dan mempercepat konvergensi, suatu bobot inersia yang mengecil nilainya dengan bertambahnya iterasi digunakan dengan formula:

$\theta(\mathrm{i})=\theta_{\max }-\left(\frac{\theta_{\max }-\theta_{\min }}{i_{\max }}\right) i$

dimana $\theta$ max dan $\theta$ min masing-masing adalah nilai awal dan nilai akhir bobot inersia, imax adalah jumlah iterasi maksimum yang digunakan dan $i$ adalah iterasi yang sekarang. Biasanya digunakan nilai $\theta \max =0.9$ dan $\theta \min =0.4$. Perubahan atau modifikasi formula untuk mengupdate kecepatan ini seperti step size $\alpha$ dalam algoritma Steepest Descent, dimana nilai $\alpha$ yang terlalu besar akan memungkinan suatu local optimum akan terlewati sehingga algoritma justru menemukan local optimal yang lain yang tidak lebih baik nilainya.

\subsection{Kombinasi FCM dan PSO}

Pustaka [7] mengusulkan PSO yang telah dimodifikasi untuk Traveling Salesman Problem (TSP) yang disebut Fuzzy Particle Swarm Optimization (FPSO). Dalam metode yang mereka usulkan posisi dan kecepatan partikel didefinisikan ulang untuk mewakilihubungan antar variabel fuzzy. Dalam algoritma FPSOX, posisi partikel, menunjukkan hubungan fuzzy dari sekumpulan objek data, $0=\{01,02, \ldots$, on $\}$, untuk mengatur pusat kluster, $Z=\{z 1, z 2, \ldots, z c\}$. X dapat dinyatakan sebagai berikut:

$$
X=\left[\begin{array}{ccc}
\mu_{11} & \cdots & \mu_{1 c} \\
\vdots & \ddots & \vdots \\
\mu_{n 1} & \cdots & \mu_{n c}
\end{array}\right]
$$

Di mana:

= fungsi keanggotaan pada objek ke - I dengan kluster ke - j ij Apabila kita perhatikan matriks posisi untuk setiap partikel di atas sama dengan matriks fuzzy $\mu$ pada algoritma FCM. Kecepatan setiap 
partikel dinyatakan dengan matriks dengan ukuran baris $n$ dan kolom $c$ pada rentang nilai elemen $[0,1]$. Untuk memperbarui posisi dan kecepatan partikel digunakan persamaan berikut berdasarkan operasi matriks:

$V_{t+1}=W^{*} V_{t}+c 1^{*} r 1^{*}\left(\right.$ Pbest $\left._{t}-X_{t}\right)+C 2^{*} r 2^{*}\left(\right.$ Gbest $\left.t_{t}-X_{t}\right)$. $\ldots \ldots(15)$

$X_{t+1}=X_{t} \oplus V_{t+1}$

Operator " $\oplus$ " digunakan untuk menunjukkan bahwa operasi penambahan yang dilakukan adalah operasi penambahan antar matriks [7]. Dalam pelaksanaan penghitungannya ada kemungkinan nilai yang dihasilkan tidak sesuai dengan syarat rentang $[0,1]$ maka perlu ditransformasikan dengan matriks berikut :

Xnormal $=\left(\begin{array}{ccc}\frac{\mu_{i 1}}{\sum_{j=1}^{c} \mu_{i j}} & \cdots & \frac{\mu_{i c}}{\sum_{j=1}^{c} \mu_{i j}} \\ \vdots & \ddots & \vdots \\ \frac{\mu_{n 1}}{\sum_{j=1}^{c} \mu_{n j}} & \cdots & \frac{\mu_{n c}}{\sum_{j=1}^{c} \mu_{n j}}\end{array}\right)$

Fungsi untuk mengevaluasi hasil dari operasi di atas disebut fungsi fitness:

$f(x)=\frac{\mathrm{K}}{\mathrm{J}_{\mathrm{m}}}$

Di mana: $\mathrm{K}=$ Konstanta

$\mathrm{Jm}=$ Fungsi objektif FCM

Berdasarkan uraian teori di atas maka dapat dibangun algoritma FPSO sebagai berikut:

1. Inisialisasi parameter (ukuran populasi $P, \mathrm{c1}$, c2, w dan iterasi maksimum).

2. Buat sebuah swarm sejumlah partikel $P(X$, pbest, gbest dan $\mathrm{V}$ adalah matriks $\mathrm{n} \times \mathrm{c}$; di mana $n$ adalah jumlah data dan $c$ adalah jumlah kluster yang ada).

3. Inisialisasi $\mathrm{X}, \mathrm{V}$ dan pbest untuk setiap partikel dan gbest untuk swarm.

4. Hitung pusat kluster untuk setiap partikel menggunakan persamaan (4).

5. Hitung nilai fitness untuk setiap partikel menggunakan persamaan (17).

6. Hitung pbest untuk setiap partikel.

7. Hitung gbest untuk swarm.

8. Perbarui matriks kecepatan untuk setiap partikel menggunakan persamaan(8).

9. Perbarui matriks posisi untuk setiap partikel menggunakan persamaan (9).

10. Apabila kondisi terminasi tidak dicapai kembali ke langkah 4.

\subsection{Pengelompokan Kelas Belajar} menggunkan FCM dengan Optimasi PSO pembobotan pemilihan pusat cluster

Didalam ekperimen model pengelompokan kelas yang penulis lakukan mengacu pada penelitian terdahulu dan mencoba menyempurnakannya dalam alogritma Fuzzy CMeans yang akan di optimasi oleh algoritma Particle Swarms Optimation (PSO) untuk memaksimalkan hasil clustering dikarenakan pada algorima $\mathrm{K}$ Means maupun Fuzzy C-Means mempunyai kelemahan penentuan dipusat awal cluster dang sering terjebak dalam solusi local.

Tiap-tiap data memiliki derajat keanggotaan pada tiap-tiap cluster. Dengan cara memperbaiki pusat cluster dan derajat keanggotaan tiap-tiap data secara berulang-ulang, maka didapat lokasi pusat cluster optimal. Perulangan ini didasarkan pada fungsi obyektif yang menggambarkan jarak dari titik data yang diberikan ke pusat cluster yang terbobot oleh derajat keanggotaan titik data tersebut.

Optimasi PSO dipakai untuk menentukan atau mencari pusat awal cluster yang terbaik untuk menghasilkan cluster yang optimal dengan keanggotaan yang ideal. Indikator pada Fuzzy CMeans adalah dengan mengetahui fungsi objektif dan fungsi keanggotaan yang maksimum dalam suatu cluster dan iterasi minimum untuk mencapai selisih yang diharapkan. Sedangkan pada PSO indikator bobot inersia, konstanta dan global best untuk menemukan titik awal pusat cluster atau centroit yang terbaik.

Bobot inersia digunakan untuk meredam kecepatan selama iterasi, yang memungkinkan kawanan burung menuju (konverge) titik target secara lebih akurat dan efisien dibandingkan dengan algoritma aslinya. Nilai bobot inersia yang tinggi menambah porsi pencarian global (global exploration), sedangkan nilai yang rendah lebih menekankan pencarian lokal (local search). Untuk tidak terlalu menitik beratkan pada salah satu bagian dan tetap mencari area pencarian yang baru dalam ruang berdimensi tertentu, maka perlu dicari nilai bobot inersia $(\theta)$ yang secara imbang menjaga pencarian global dan lokal. Untuk mencapai itu dan mempercepat konvergensi, suatu bobot inersia yang mengecil nilainya dengan bertambahnya iterasi. Perubahan atau modifikasi formula untuk mengupdate kecepatan ini seperti step size $\alpha$ dalam algoritma Steepest Descent, dimana nilai $\alpha$ yang terlalu besar akan memungkinan suatu local optimum akan terlewati sehingga algoritma justru menemukan local optimal yang lain yang tidak lebih baik nilainya. 


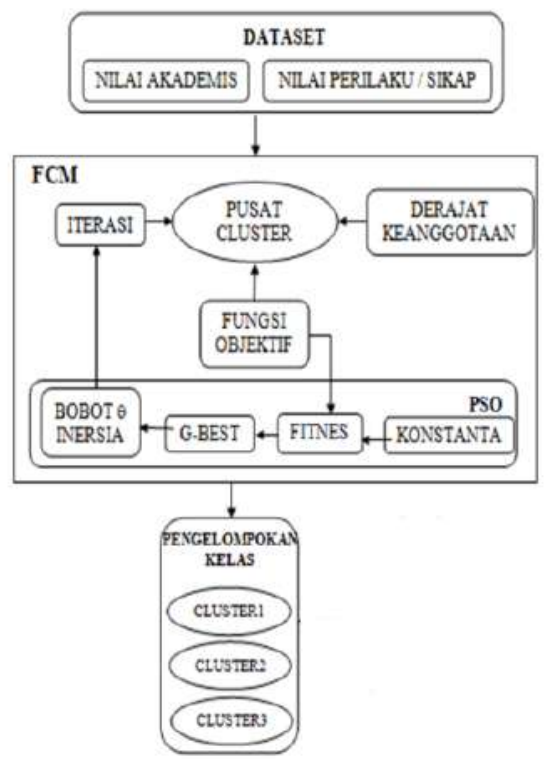

Gambar 1. Kerangka Pemikiran

\section{Metode Penelitian}

\subsection{Pengumpulan Data}

Pengumpulan Data (Data Gathering), Pada bagian ini dijelaskan tentang bagaimana dan darimana data dalam penelitian ini didapatkan, ada dua tipe dalam pengumpulan data, yaitu pengumpulan data primer dan pengumpulan data sekunder. Data primer adalah data yang dikumpulkan pertama kali untuk melihat apa yang sesungguhnya terjadi. Data sekunder adalah data yang sebelumnya pernah dibuat oleh seseorang baik di terbitkan atau tidak. Pengumpulan data primer bisa didapat dari model interview terhadap responden, maupun dengan model observasi terhadap suatu badan yang sedang diteliti. Pada tahap ini ditentukan data yang akan diproses. Mencari data yang tersedia, memperoleh data tambahan yang dibutuhkan, mengintegrasikan semua data kedalam data set, termasuk variabel yang diperlukan dalam proses.

Pemilihan data set yang digunakan dalam penelitian ini adalah data privat yang sebelumnya belum pernah dipakai dalam penelitian data mining. Meskipun data dari Nilai Akademik sudah sering digunakan, tetapi jenis raportnya berbeda dengan sekolah SMA ataupun SMK nasional lainnya, sesuai dengan kebijakan yayasan sekolah tersebut, yang berada dibawah naungan pondok pesantren modern.

\subsubsection{Dataset Raport}

Dataset yang akan digunakan adalah Raport Seluruh Siswa Kelas X, XI, XII TKJ (Teknik Komputer dan Jaringan) SMK Askhabul Kahfi Semarang Tahun 2015/2016yang terdiri dari 403 data nilai siswa. Variabel dari nilai akademis yang terdiri dari nilai Normatif, Adaptif, Produktif serta Muatan Lokal yang berasal dari kebijakan Yayasan SMK tersebut bernaung yaitu Pondok Pesantren Nurul ITTIFAQ Semarang. Variabel tersebut akan mewakili nilai raport akademis diantaranya adalah :

N1 : PAI (Pendidikan Agama Islam)

N2 : PKn (Pendidikan Kewarganegaraan)

N3 : Bahasa Indonesia,

N4 : PJOK (Olah Raga)

N5 : Seni Budaya,

A6 : B.Inggris,

A7 : Matematika,

A8 : IPA,

A9 : Kimia,

A10 : Fisika, A11 :IPS,

A12 : KKPI,

A13 : KWU,

M19 : Sulam Sibyan,

M20 : Safinah,

M21 : Tajwid,

M22 : Taklim,

M23 : Al-Quran,

M24 : Tasrif.

P14 : PRODUKTIF1 (Merakit PC)

P15 : PRODUKTIF2 (Elektronika Dasar)

P16 : PRODUKTIF3 (Perawatan PC)

P17 : PRODUKTIF4 (Trobleshooting PC)

P18 : PRODUKTIF5 (Keselamatan Kerja)

Tabel 1. Nilai Akademik 


\begin{tabular}{|c|c|c|c|c|c|c|c|c|c|c|c|c|c|c|c|c|c|}
\hline 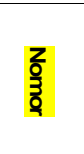 & $\stackrel{D}{2}$ & 꾹 & 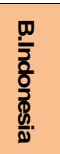 & ర্ & 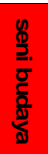 & $\begin{array}{l}\frac{w}{\bar{z}} \\
\frac{0}{0} \\
\frac{0}{\bar{\omega}}\end{array}$ & 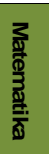 & $\bar{\nabla}$ & 졸 & $\frac{\frac{T}{T}}{\frac{\bar{\omega}}{\overline{\hat{\theta}}}}$ & $\overline{\mathrm{D}}$ & 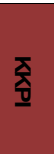 & હૂ & 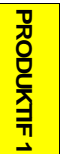 & 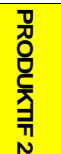 & 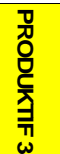 & 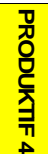 \\
\hline & \multicolumn{5}{|c|}{ Normatif } & \multicolumn{8}{|c|}{ Adaptif } & \multicolumn{4}{|c|}{ Produktif } \\
\hline 0 & 1 & 2 & 3 & 4 & 5 & 1 & 2 & 3 & 4 & 5 & 6 & 7 & 8 & 1 & 2 & 3 & 4 \\
\hline KKM & 75 & 75 & 75 & 75 & 75 & 75 & 75 & 75 & 75 & 75 & 75 & 75 & 75 & 75 & 75 & 75 & 75 \\
\hline 1 & 75 & 76 & 77 & 78 & 79 & 80 & 81 & 82 & 83 & 84 & 85 & 86 & 87 & 88 & 89 & 90 & 91 \\
\hline 2 & 84 & 82 & 79 & 85 & 75 & 85 & 80 & 85 & 78 & 82 & 82 & 79 & 76 & 86 & 86 & 86 & 86 \\
\hline 3 & 92 & 85 & 89 & 80 & 76 & 88 & 79 & 88 & 82 & 77 & 87 & 91 & 85 & 84 & 84 & 84 & 84 \\
\hline 4 & 87 & 85 & 95 & 81 & 80 & 87 & 80 & 85 & 90 & 80 & 80 & 80 & 79 & 82 & 82 & 82 & 82 \\
\hline 5 & 92 & 80 & 90 & 85 & 80 & 85 & 81 & 80 & 78 & 84 & 85 & 79 & 79 & 84 & 84 & 84 & 84 \\
\hline 6 & 84 & 80 & 83 & 85 & 78 & 85 & 86 & 80 & 75 & 78 & 79 & 85 & 78 & 82 & 82 & 82 & 82 \\
\hline 7 & 79 & 80 & 91 & 82 & 45 & 67 & 87 & 80 & 75 & 78 & 77 & 76 & 80 & 82 & 82 & 82 & 82 \\
\hline 8 & 79 & 80 & 81 & 85 & 56 & 65 & 54 & 80 & 75 & 78 & 77 & 76 & 65 & 79 & 70 & 45 & 79 \\
\hline 9 & 82 & 85 & 84 & 84 & 80 & 85 & 80 & 85 & 75 & 76 & 82 & 88 & 78 & 88 & 88 & 88 & 88 \\
\hline 10 & 85 & 70 & 77 & 82 & 65 & 76 & 67 & 75 & 75 & 76 & 88 & 85 & 86 & 86 & 86 & 86 & 86 \\
\hline 11 & 78 & 70 & 75 & 83 & 72 & 72 & 71 & 78 & 85 & 75 & 88 & 80 & 88 & 88 & 88 & 88 & 88 \\
\hline 12 & 75 & 70 & 77 & 82 & 83 & 68 & 72 & 75 & 75 & 75 & 88 & 79 & 88 & 88 & 88 & 88 & 88 \\
\hline & $\ldots$ & $\ldots$ & $\ldots$ & $\ldots$ & $\ldots$ & $\ldots$ & $\ldots$ & $\ldots$ & $\ldots$ & $\ldots$ & $\ldots$ & $\ldots$ & $\ldots$ & $\ldots$ & $\ldots$ & $\ldots$ & $\ldots$ \\
\hline & $\ldots$ & $\ldots$ & $\ldots$ & $\ldots$ & $\ldots$ & $\ldots$ & $\ldots$ & $\ldots$ & $\ldots$ & $\ldots$ & $\ldots$ & $\ldots$ & $\ldots$ & $\ldots$ & $\ldots$ & $\ldots$ & $\ldots$ \\
\hline 397 & 66 & 52 & 55 & 61 & 54 & 38 & 84 & 77 & 71 & 72 & 64 & 64 & 61 & 58 & 52 & 71 & 65 \\
\hline 398 & 71 & 52 & 53 & 61 & 46 & 46 & 77 & 80 & 81 & 73 & 53 & 33 & 74 & 60 & 59 & 69 & 70 \\
\hline 399 & 84 & 84 & 84 & 80 & 90 & 95 & 85 & 81 & 80 & 90 & 92 & 80 & 90 & 85 & 80 & 85 & 81 \\
\hline 400 & 82 & 82 & 82 & 60 & 64 & 95 & 85 & 86 & 80 & 95 & 84 & 80 & 83 & 85 & 78 & 85 & 86 \\
\hline 401 & 82 & 82 & 82 & 56 & 87 & 95 & 80 & 87 & 80 & 90 & 79 & 80 & 91 & 82 & 45 & 67 & 87 \\
\hline 402 & 45 & 79 & 79 & 46 & 45 & 95 & 80 & 85 & 80 & 85 & 79 & 80 & 81 & 85 & 56 & 65 & 54 \\
\hline 403 & 88 & 88 & 88 & 76 & 98 & 95 & 85 & 80 & 85 & 84 & 82 & 85 & 84 & 84 & 80 & 85 & 80 \\
\hline
\end{tabular}

\begin{tabular}{|c|c|c|c|c|c|c|}
\hline 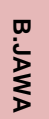 & 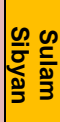 & 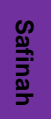 & $\frac{\overrightarrow{0}}{\frac{0}{0}}$ & $\begin{array}{l}\frac{\vec{w}}{\overline{\underline{m}}} \\
\overrightarrow{\bar{\xi}}\end{array}$ & 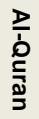 & ְֶֶ \\
\hline \multicolumn{7}{|c|}{ Muatan Lokal } \\
\hline 1 & 2 & 3 & 4 & 5 & 6 & 7 \\
\hline 75 & 75 & 75 & 75 & 75 & 75 & 75 \\
\hline 80 & 80 & 95 & 80 & 81 & 82 & 90 \\
\hline 68 & 76 & 95 & 85 & 80 & 85 & 85 \\
\hline 90 & 46 & 95 & 88 & 79 & 88 & 84 \\
\hline 70 & 67 & 95 & 87 & 80 & 85 & 90 \\
\hline 80 & 90 & 95 & 85 & 81 & 80 & 90 \\
\hline 60 & 64 & 95 & 85 & 86 & 80 & 95 \\
\hline 56 & 87 & 95 & 80 & 87 & 80 & 90 \\
\hline 46 & 45 & 95 & 80 & 85 & 80 & 85 \\
\hline 76 & 98 & 95 & 85 & 80 & 85 & 84 \\
\hline 86 & 92 & 96 & 95 & 93 & 78 & 90 \\
\hline 88 & 85 & 90 & 85 & 93 & 76 & 86 \\
\hline 88 & 72 & 76 & 78 & 85 & 79 & 70 \\
\hline$\ldots$ & $\ldots$ & $\ldots$ & $\ldots$ & $\ldots$ & $\ldots$ & $\ldots$ \\
\hline$\ldots$ & $\ldots$ & $\ldots$ & $\ldots$ & $\ldots$ & $\ldots$ & $\ldots$ \\
\hline 62 & 71 & 63 & 62 & 82 & 67 & 78 \\
\hline 72 & 72 & 74 & 73 & 78 & 63 & 75 \\
\hline 78 & 84 & 80 & 78 & 84 & 85 & 79 \\
\hline 75 & 78 & 80 & 75 & 78 & 79 & 85 \\
\hline 75 & 78 & 80 & 75 & 78 & 77 & 76 \\
\hline 75 & 78 & 80 & 75 & 78 & 77 & 76 \\
\hline 75 & 76 & 85 & 75 & 76 & 82 & 88 \\
\hline
\end{tabular}

\subsubsection{Dataset Nilai Sikap}

Sedangkan nilai sikap anak - anak yang dihasilkan dari survei semua guru yang mengajar kelas tersebut dan telah di rangkum menjadi beberapa point nilai dengan variabel sebagai berikut :

Tabel 2. Nilai Perilaku / Sikap

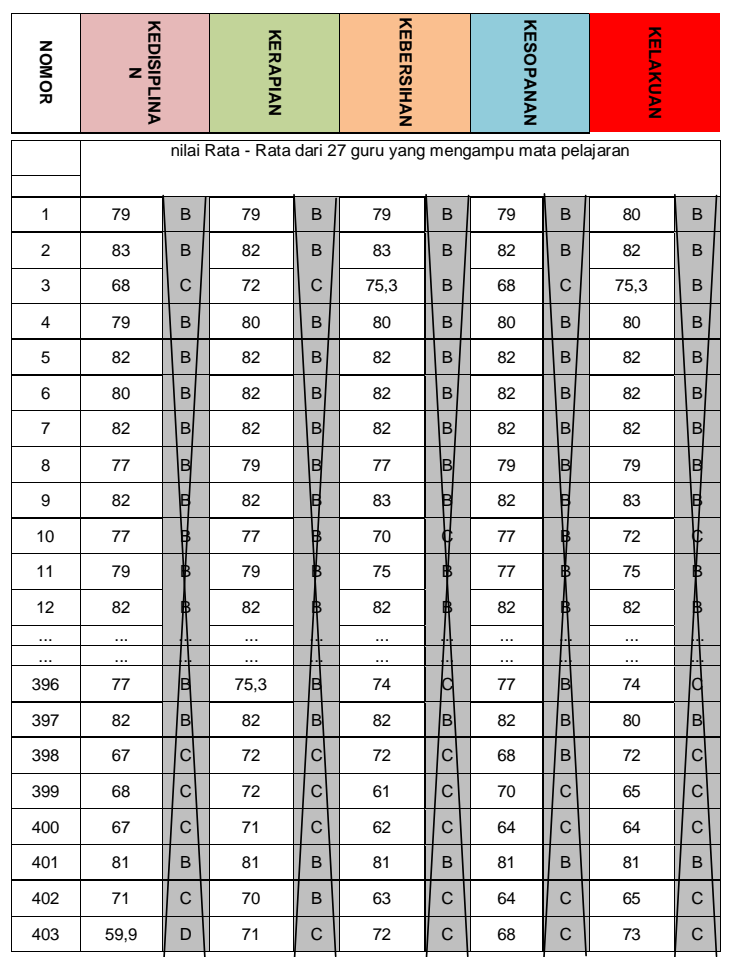

K1 : Kedisiplinan, adalah suatu sikap dan perilaku yang mencerminkan ketaatan dan ketepatan terhadap peraturan, tata 
tertib,norma-norma yang berlaku,baik tertulis maupun yang tidak tertulis.

K2 : Kerapian, adalah sikap dan perilaku kita yang menunjukkan kebersihan dan keteraturan.

K3 : Kebersihan, adalah keadaan bebas dari kotoran, termasuk di antaranya, debu, sampah, dan bau.

K4 : Kesopanan, peraturan sosial yang mengarah ke hal-hal berkenaan dengan cara seseorang bertingkah laku wajar dalam kehidupan bermasyarakat.

K5 : Kelakuan, adalah pola kebudayaan (cultural pattern) yang juga bersifat memaksa seperti hukum (nomotetik).

\subsection{Preprocessing}

Pengolahan Awal Data (Data Preprocessing)yaitu data perolehan di bersihkan dari noise dan outlier atau proses cleaning dan di normalisasi min max untuk mendapatkan atribut yang relevan, ringkas dan sesuai dengan format input algoritma Fuzzy C-Means dan particle swarm optimization (PSO)

\subsubsection{Data Cleaning}

Data yang tidak berkualitas akan menghasilkan data mining yang tidak berkualitas. Keputusan yang berkualitas harus didasarkan pada data yang berkualitas. Data yang hilang akan menyebabkan ketidakbenaran atau menyesatkan. Ekstraksi data, pembersihan, dan transformasi data merupakan tugas utama dalam data warehause.

Tugas-tugas data cleaning:

a) Mengisi nilai data yang hilang dan tidak lengkap (missingvalue).

b) Mengidentifikasi atau menghilangkan outliers danmemperhalus data noise.

c) Memperbaiki ketidak konsistenan data.

d) Memecahkan redudansi yang disebabkan oleh integrasi data.

\subsubsection{Normalisasi Data Min Max}

Normalisasi data min max adalah memperkecil data atribut pada kisaran atau interval tertentu. Standarisasi data dengan menempatkan data dalam range 0 sampai 1 , nilai terkecil sebagai 0 , dan nilai terbesar sebagai 1 [14].

keterangan :

$$
x \text { normalisasi }=\frac{(x-x \min )}{(x \max -x \min )}
$$

$x \quad$ : data asli

$x$ min : nilai minimal dari data

$x \max$ : nilai maximal dari data

Keuntungan dari metode ini adalah keseimbangan nilai perbandingan antar data saat sebelum dan sesudah proses normalisasi. Tidak ada data bias yang dihasilkan oleh metode ini. Kekurangannya adalah jika ada data baru, metode ini akan memungkinkan terjebak pada "out of bound" error.

\subsection{Algoritma yang diusulkan}

Dari hasil penetian dari daftra pustaka terdahulu maka penulis mengajukan algorima FCM yang di gabungkan dengan PSO untuk penentuan pusat cluster sebagai berikut :

1. Normalisasi dengan persamaan min-max

2. Inisialisasi parameter FPSO $\left(\mathrm{P}, \mathrm{c}_{1}, \mathrm{c}_{2}, \varepsilon, w\right.$ dan m)

3. Membentuk swarm sejumlah $\mathrm{P}$ secara random

4. Hitung pusat cluster untuk masing partikel menggunakan (persamaan 8)

$$
V_{k j}=\frac{\sum_{i=1}^{n}\left(\left(\mu_{i k}\right)^{m} \cdot X_{i j}\right)}{\sum_{i=1}^{n}\left(\mu_{i k}\right)^{m}}
$$

5. Hitung fungsi objektif masing - masing partikel menggunakan (persamaa 9)

$$
P_{t}=\sum_{i=1}^{n} \sum_{k=1}^{c}\left(\left[\sum_{j=1}^{a t r}\left(X_{i j}-V_{k j}\right)^{2}\right] \cdot\left(\mu_{i k}\right)^{m}\right)
$$

6. Menentukan Pbest dan Gbest

7. Update nilai velocity dan nilai posisi setiap partikel (persamaan 18)

$V_{t+1}=w^{*} V_{t}+c 1^{*} r 1^{*}\left(\right.$ Pbest $\left._{t}-X_{t}\right)+C 2^{*}{ }^{*}{ }^{*}\left(\right.$ Gbest $_{t}-$ $\left.X_{t}\right) X_{t+1}=X_{t}+V_{t+1}$

8. Subiterasi fcm, untuk setiap partikel:

8.1 Hitung pusat cluster

8.2 Hitung fungsi objektif

8.3 Akhiri subiterasi jika selisih fungsi objektif saat ini dan sebelumnya $<$ nilai $\varepsilon$

8.4 Update nilai Partikel jika selisih fungsi objektif saat ini dan sebelumnya > nilai $\varepsilon$, kembali ke 7.1

8.5 Tentukan Pbest dan Gbest

9. Akhiri iterasi jika Gbest tidak mengalami perubahan dalam $\mathrm{m}$ kali iterasi berturutturutatau iterasi mencapai jumlah maksimum

10. Kembali ke langkah 6 jika Gbest mengalami perubahan

\section{Pembahasan Metode}

\subsection{Hasil Normalisasi Max Min}

Pertama kali sebelum melakukan eksperimen mengenai pengelompokkan kelas dataset nilai akademis nilai angkanya dinormalisi dengan metode normalisi max min, dimana nilai max atau nilai tertinggi adalah 100 dan nilai minimum atau nilai terendah ada yang mendapat nilai 30 , secara rumus excel metode normalisasi max min di presentasikan menjadi rumus cell dibawah ini :

$$
\text { "=(Sheet } 1 ! \mathrm{A} 1-
$$

MIN(Sheet1!\$A\$1:\$AC\$403))/(MAX(Sheet1!\$J \$1:\$AC\$403)-MIN (Sheet1!\$J\$1:\$AC\$403))"

Hasil dari normalisasi max min dibawah ini yang nantinya akan dieksekusi oleh mathlab dalam metode clustering Fuzzy C-Means dan PSO dan urutannya yang masih sesuai dengan absensi sebagai berikut :

Tabel 3. Hasil normalisasi nilai akademis 


\begin{tabular}{|c|c|c|c|c|c|c|c|c|c|c|c|c|c|c|c|c|c|}
\hline 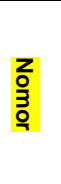 & $\underline{\underline{Z}}$ & 즉 & 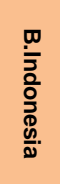 & $\begin{array}{l}\text { 듯 } \\
\text { 이 }\end{array}$ & 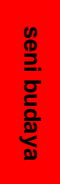 & 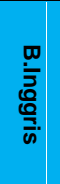 & 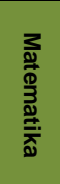 & $\bar{\nabla}$ & 즐 & $\frac{\frac{\pi}{\vec{\omega}}}{\frac{\hat{\omega}}{\hat{\theta}}}$ & $\overline{\tilde{D}}$ & 页 & $\sum_{\Sigma}^{\pi}$ & 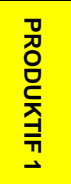 & 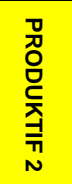 & 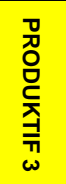 & 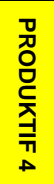 \\
\hline & \multicolumn{5}{|c|}{ Normatif } & \multicolumn{8}{|c|}{ Adaptif } & \multicolumn{4}{|c|}{ Produktif } \\
\hline & 1 & 2 & 3 & 4 & 5 & 1 & 2 & 3 & 4 & 5 & 6 & 7 & 8 & 1 & 2 & 3 & 4 \\
\hline 1 & 0,75 & 0,74 & 0,72 & 0,82 & 0,86 & 0,72 & 0,74 & 0,75 & 0,79 & 0,76 & 0,88 & 0,78 & 0,86 & 0,86 & 0,86 & 0,86 & 0,86 \\
\hline 2 & 0,85 & 0,70 & 0,77 & 0,82 & 0,71 & 0,72 & 0,87 & 0,78 & 0,81 & 0,75 & 0,88 & 0,79 & 0,86 & 0,86 & 0,86 & 0,86 & 0,86 \\
\hline 3 & 0,80 & 0,70 & 0,75 & 0,80 & 0,75 & 0,70 & 0,53 & 0,72 & 0,75 & 0,75 & 0,83 & 0,77 & 0,86 & 0,86 & 0,86 & 0,86 & 0,86 \\
\hline 4 & 0,76 & 0,72 & 0,75 & 0,80 & 0,67 & 0,74 & 0,79 & 0,74 & 0,81 & 0,75 & 0,86 & 0,70 & 0,83 & 0,83 & 0,83 & 0,83 & 0,83 \\
\hline 5 & 0,80 & 0,74 & 0,73 & 0,83 & 0,65 & 0,74 & 0,71 & 0,75 & 0,85 & 0,77 & 0,83 & 0,79 & 0,86 & 0,86 & 0,86 & 0,86 & 0,86 \\
\hline 6 & 0,90 & 0,74 & 0,80 & 0,82 & 0,67 & 0,88 & 0,86 & 0,75 & 0,85 & 0,75 & 0,92 & 0,85 & 0,88 & 0,88 & 0,88 & 0,88 & 0,88 \\
\hline 7 & 0,90 & 0,75 & 0,75 & 0,82 & 0,54 & 0,86 & 0,86 & 0,76 & 0,77 & 0,75 & 0,88 & 0,80 & 0,88 & 0,88 & 0,88 & 0,88 & 0,88 \\
\hline 8 & 0,80 & 0,70 & 0,71 & 0,82 & 0,73 & 0,74 & 0,60 & 0,75 & 0,79 & 0,75 & 0,86 & 0,79 & 0,88 & 0,88 & 0,88 & 0,88 & 0,88 \\
\hline 9 & 0,85 & 0,70 & 0,77 & 0,82 & 0,65 & 0,76 & 0,67 & 0,75 & 0,75 & 0,76 & 0,88 & 0,85 & 0,86 & 0,86 & 0,86 & 0,86 & 0,86 \\
\hline 10 & 0,78 & 0,70 & 0,75 & 0,83 & 0,72 & 0,72 & 0,71 & 0,78 & 0,85 & 0,75 & 0,88 & 0,80 & 0,88 & 0,88 & 0,88 & 0,88 & 0,88 \\
\hline 11 & 0,75 & 0,70 & 0,77 & 0,82 & 0,83 & 0,68 & 0,72 & 0,75 & 0,75 & 0,75 & 0,88 & 0,79 & 0,88 & 0,88 & 0,88 & 0,88 & 0,88 \\
\hline$\ldots \ldots$ & $\ldots \ldots$ & $\ldots \ldots$ & $\ldots \ldots$ & $\ldots \ldots$ & $\ldots \ldots$ & $\ldots \ldots$ & $\ldots \ldots$ & $\ldots \ldots$ & $\ldots \ldots$ & $\ldots \ldots$ & $\ldots \ldots$ & $\ldots \ldots$ & $\ldots \ldots$ & $\ldots \ldots$ & $\ldots \ldots$ & $\ldots \ldots$. & $\ldots \ldots$ \\
\hline$\ldots \ldots$ & $\ldots \ldots$ & $\ldots \ldots$ & $\ldots \ldots$ & $\ldots \ldots$ & $\ldots \ldots$ & $\ldots \ldots$ & $\ldots \ldots$ & $\ldots \ldots$ & $\ldots \ldots$ & $\ldots \ldots$ & $\ldots \ldots$ & $\ldots \ldots$ & $\ldots \ldots$ & $\ldots \ldots$ & $\ldots \ldots$ & $\ldots \ldots$. & $\ldots \ldots$ \\
\hline$\ldots \ldots$ & $\ldots \ldots$ & $\ldots \ldots$ & $\ldots \ldots$ & $\ldots \ldots$ & $\ldots \ldots$ & $\ldots \ldots$ & $\ldots \ldots$ & $\ldots \ldots$ & $\ldots \ldots$ & $\ldots \ldots$ & $\ldots \ldots$ & $\ldots \ldots$ & $\ldots \ldots$ & $\ldots \ldots$ & $\ldots \ldots$ & $\ldots \ldots$. & $\ldots \ldots$ \\
\hline 397 & 0,66 & 0,52 & 0,55 & 0,61 & 0,54 & 0,38 & 0,84 & 0,77 & 0,71 & 0,72 & 0,64 & 0,64 & 0,61 & 0,58 & 0,52 & 0,71 & 0,65 \\
\hline 398 & 0,71 & 0,52 & 0,53 & 0,61 & 0,46 & 0,46 & 0,77 & 0,80 & 0,81 & 0,73 & 0,53 & 0,33 & 0,74 & 0,60 & 0,59 & 0,69 & 0,70 \\
\hline 399 & 0,73 & 0,63 & 0,67 & 0,63 & 0,63 & 0,61 & 0,72 & 0,65 & 0,69 & 0,65 & 0,47 & 0,44 & 0,75 & 0,62 & 0,56 & 0,76 & 0,56 \\
\hline 400 & 0,53 & 0,59 & 0,48 & 0,72 & 0,66 & 0,66 & 0,28 & 0,62 & 0,47 & 0,64 & 0,46 & 0,33 & 0,66 & 0,48 & 0,43 & 0,74 & 0,50 \\
\hline 401 & 0,56 & 0,45 & 0,63 & 0,74 & 0,67 & 0,64 & 0,53 & 0,56 & 0,56 & 0,58 & 0,50 & 0,46 & 0,74 & 0,60 & 0,51 & 0,81 & 0,59 \\
\hline 402 & 0,62 & 0,46 & 0,55 & 0,76 & 0,68 & 0,67 & 0,40 & 0,48 & 0,58 & 0,67 & 0,62 & 0,73 & 0,66 & 0,49 & 0,42 & 0,77 & 0,54 \\
\hline 403 & 0,65 & 0,66 & 0,63 & 0,72 & 0,69 & 0,70 & 0,58 & 0,40 & 0,35 & 0,68 & 0,53 & 0,45 & 0,62 & 0,49 & 0,43 & 0,74 & 0,58 \\
\hline
\end{tabular}

Tabel 4. Hasil normalisai nilai perilaku atau sikap 


\begin{tabular}{|c|c|c|c|c|c|c|}
\hline 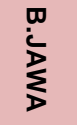 & 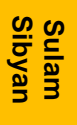 & 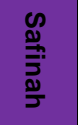 & 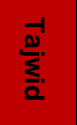 & $\begin{array}{l}\frac{1}{\sqrt[0]{x}} \\
\frac{\overline{\bar{B}}}{3}\end{array}$ & 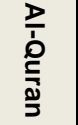 & $\begin{array}{l}-1 \\
0 \\
0 \\
\Rightarrow \\
\Rightarrow\end{array}$ \\
\hline \multicolumn{7}{|c|}{ Muatan Lokal } \\
\hline 1 & 2 & 3 & 4 & 5 & 6 & 7 \\
\hline 0,88 & 0,85 & 0,94 & 0,90 & 0,85 & 0,76 & 0,80 \\
\hline 0,86 & 0,80 & 0,82 & 0,78 & 0,77 & 0,82 & 0,82 \\
\hline 0,86 & 0,78 & 0,82 & 0,85 & 0,83 & 0,80 & 0,80 \\
\hline 0,86 & 0,81 & 0,78 & 0,78 & 0,83 & 0,76 & 0,72 \\
\hline 0,83 & 0,85 & 0,80 & 0,92 & 0,85 & 0,76 & 0,80 \\
\hline 0,86 & 0,75 & 0,75 & 0,80 & 0,77 & 0,79 & 0,70 \\
\hline 0,88 & 0,90 & 0,70 & 0,90 & 0,77 & 0,80 & 0,75 \\
\hline 0,88 & 0,82 & 0,78 & 0,86 & 0,78 & 0,79 & 0,75 \\
\hline 0,88 & 0,78 & 0,82 & 0,92 & 0,90 & 0,80 & 0,83 \\
\hline 0,86 & 0,92 & 0,96 & 0,95 & 0,93 & 0,78 & 0,90 \\
\hline 0,88 & 0,85 & 0,90 & 0,85 & 0,93 & 0,76 & 0,86 \\
\hline 0,88 & 0,72 & 0,76 & 0,78 & 0,85 & 0,79 & 0,70 \\
\hline$\ldots$ & $\ldots$ & $\ldots$ & $\ldots$ & $\ldots$ & $\ldots$ & $\ldots$ \\
\hline$\ldots$ & $\ldots$ & $\ldots$ & $\ldots$ & $\ldots$ & $\ldots$ & $\ldots$ \\
\hline 0,62 & 0,71 & 0,63 & 0,62 & 0,82 & 0,67 & 0,78 \\
\hline 0,72 & 0,72 & 0,74 & 0,73 & 0,78 & 0,63 & 0,75 \\
\hline 0,58 & 0,62 & 0,40 & 0,32 & 0,71 & 0,72 & 0,72 \\
\hline 0,48 & 0,52 & 0,42 & 0,42 & 0,73 & 0,62 & 0,60 \\
\hline 0,46 & 0,57 & 0,62 & 0,54 & 0,62 & 0,52 & 0,45 \\
\hline 0,49 & 0,73 & 0,51 & 0,45 & 0,66 & 0,51 & 0,32 \\
\hline 0,53 & 0,77 & 0,57 & 0,40 & 0,54 & 0,41 & 0,25 \\
\hline
\end{tabular}

\subsection{Perhitungan Algoritma FCM + PSO}

Pada perhitungan kali ini perhitungan algoritma yang akan dibahas adalah langsung pada perhitungan Fuzzy C Means dan PSO dengan metode yang diusulkan dimana peneliti meneliti sample datanya yang diambil dari dataset. Yang

\begin{tabular}{|c|c|c|c|c|c|}
\hline $\begin{array}{l}\text { zo } \\
\text { ō } \\
\text { oำ }\end{array}$ & 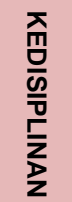 & $\begin{array}{l}\text { 面 } \\
\text { 齐 } \\
\text { 竞 }\end{array}$ & $\begin{array}{l}\text { 面 } \\
\text { 啰 } \\
\text { 罣 } \\
\text { 妾 }\end{array}$ & $\begin{array}{l}\text { 圌 } \\
\text { O } \\
\text { D } \\
\text { z } \\
\text { z }\end{array}$ & 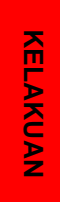 \\
\hline 1 & 0,70 & 0,75 & 0,80 & 0,75 & 0,70 \\
\hline 2 & 0,72 & 0,75 & 0,80 & 0,67 & 0,74 \\
\hline 3 & 0,74 & 0,73 & 0,83 & 0,65 & 0,74 \\
\hline 4 & 0,74 & 0,80 & 0,82 & 0,67 & 0,88 \\
\hline 5 & 0,75 & 0,75 & 0,82 & 0,54 & 0,86 \\
\hline 6 & 0,70 & 0,71 & 0,82 & 0,73 & 0,74 \\
\hline 7 & 0,70 & 0,77 & 0,82 & 0,65 & 0,76 \\
\hline 8 & 0,70 & 0,75 & 0,83 & 0,72 & 0,72 \\
\hline 9 & 0,70 & 0,77 & 0,82 & 0,83 & 0,68 \\
\hline 10 & 0,70 & 0,72 & 0,85 & 0,72 & 0,74 \\
\hline 11 & 0,74 & 0,90 & 0,79 & 0,74 & 0,86 \\
\hline 12 & 0,70 & 0,75 & 0,79 & 0,68 & 0,76 \\
\hline$\ldots$ & $\ldots$ & $\ldots$ & $\ldots$ & $\ldots$ & $\ldots$ \\
\hline$\ldots$ & $\ldots$ & $\ldots$ & $\ldots$ & $\ldots$ & $\ldots$ \\
\hline 396 & 0,70 & 0,75 & 0,82 & 0,73 & 0,78 \\
\hline 397 & 0,70 & 0,77 & 0,80 & 0,64 & 0,78 \\
\hline 398 & 0,70 & 0,70 & 0,80 & 0,73 & 0,82 \\
\hline 399 & 0,70 & 0,70 & 0,83 & 0,64 & 0,86 \\
\hline 400 & 0,74 & 0,75 & 0,84 & 0,58 & 0,84 \\
\hline 401 & 0,72 & 0,80 & 0,84 & 0,66 & 0,82 \\
\hline 402 & 0,70 & 0,72 & 0,82 & 0,71 & 0,76 \\
\hline 403 & 0,70 & 0,75 & 0,80 & 0,60 & 0,80 \\
\hline
\end{tabular}

pertama adalah menentukan matrik partisi dan velocity yang identik dengan PSO setelah digabung dengan FCM maka nilainya akan lebih baik, dimana perbedaan jika FCM tidak memakai velocity disetiap matrik partisi dataset.

Tabel 5. Penentuan matrik patisi dan velocity

\begin{tabular}{|c|c|c|c|c|c|c|c|c|c|c|c|}
\hline \multicolumn{5}{|c}{$\mathrm{P}_{1}$} & \multicolumn{4}{c|}{$\mathrm{P}_{2}$} & \multicolumn{4}{c|}{$\mathrm{P}_{3}$} \\
\hline$\mu_{\mathrm{i} 1}$ & $\mu_{\mathrm{i} 2}$ & $\mathrm{~V}_{\mathrm{i} 1}$ & $\mathrm{~V}_{\mathrm{i} 2}$ & $\mu_{\mathrm{i} 1}$ & $\mu_{\mathrm{i} 2}$ & $\mathrm{~V}_{\mathrm{i} 1}$ & $\mathrm{~V}_{\mathrm{i} 2}$ & $\mu_{\mathrm{i} 2}$ & $\mu_{\mathrm{i} 2}$ & $\mathrm{~V}_{\mathrm{i} 1}$ & $\mathrm{~V}_{\mathrm{i} 2}$ \\
\hline 0.474 & 0.526 & 1.000 & 0.600 & 0.571 & 0.429 & 0.500 & 0.300 & 0.667 & 0.333 & 0.300 & 0.900 \\
\hline 0.500 & 0.500 & 0.800 & 0.100 & 0.250 & 0.750 & 0.500 & 0.300 & 0.222 & 0.778 & 0.400 & 0.400 \\
\hline 0.400 & 0.600 & 0.200 & 0.400 & 0.100 & 0.900 & 0.800 & 0.700 & 0.500 & 0.500 & 0.500 & 0.400 \\
\hline 0.625 & 0.375 & 0.700 & 0.300 & 0.769 & 0.231 & 0.200 & 0.200 & 0.750 & 0.250 & 0.500 & 0.100 \\
\hline 0.500 & 0.500 & 0.200 & 0.700 & 0.333 & 0.667 & 0.800 & 0.100 & 0.500 & 0.500 & 1.000 & 0.100 \\
\hline 0.667 & 0.333 & 1.000 & 0.500 & 0.600 & 0.400 & 0.500 & 0.700 & 0.563 & 0.438 & 1.000 & 0.800 \\
\hline 0.714 & 0.286 & 1.000 & 0.200 & 0.231 & 0.769 & 0.300 & 0.200 & 0.667 & 0.333 & 0.400 & 1.000 \\
\hline 0.250 & 0.750 & 0.100 & 0.900 & 0.444 & 0.556 & 0.600 & 1.000 & 0.438 & 0.563 & 0.400 & 0.900 \\
\hline 0.364 & 0.636 & 0.400 & 0.600 & 0.778 & 0.222 & 0.100 & 1.000 & 0.538 & 0.462 & 1.000 & 0.600 \\
\hline 0.857 & 0.143 & 0.700 & 0.700 & 0.667 & 0.333 & 0.400 & 0.600 & 0.500 & 0.500 & 0.400 & 0.600 \\
\hline
\end{tabular}

Menentukan pusat cluster dengan rumus persamaan (4) dimana bobot atau W adalah 2 dimana $\mu_{\mathrm{i} 1} \mu_{\mathrm{i} 2}$ dipangkatkan dengan bobot tersebut menghasilkan nilai dikolom $\left(\mu_{\mathrm{i} 1}\right)^{\mathrm{w}}\left(\mu_{\mathrm{i} 2}\right)^{\mathrm{w}}$ kemudian di jumlahkan semua perkolom yang kemudian akan dijadikan pembagi untuk menentukan pusat cluster disetiap partikel.

Tabel 6. Perhitungan Pusat Cluster di Partikel 1 


\begin{tabular}{|c|c|c|c|c|c|c|c|c|c|}
\hline \multicolumn{10}{|c|}{$P_{1}$} \\
\hline$\mu_{\mathrm{i} 1}$ & $\mu_{\mathrm{i} 2}$ & $\left(\mu_{\mathrm{it} 1}\right)^{\mathrm{w}}$ & $\left(\mu_{\mathrm{i} 2}\right)^{\mathrm{w}}$ & $\left(\mu_{i 1}\right)^{w *} 0_{i 1}$ & $\left(\mu_{i 1}\right)^{w *} 0_{i 2}$ & $\begin{array}{c}\left(\mu_{i 1}\right)^{w} \\
{ }^{*} \mathrm{O}_{i 3}\end{array}$ & $\left(\mu_{i 1}\right)^{w *} 0_{i 1}$ & $\left(\mu_{i 1}\right)^{w *} o_{i 2}$ & $\begin{array}{l}\left(\mu_{i 1}\right)^{w} \\
{ }^{*} \mathrm{O}_{i 3} \\
\end{array}$ \\
\hline 0.47 & 0.53 & 0.22 & 0.28 & 1.57 & 1.57 & 2.24 & 1.94 & 1.94 & 2.77 \\
\hline 0.50 & 0.50 & 0.25 & 0.25 & 2.25 & 1.50 & 2.25 & 2.25 & 1.50 & 2.25 \\
\hline 0.40 & 0.60 & 0.16 & 0.36 & 1.28 & 1.12 & 1.44 & 2.88 & 2.52 & 3.24 \\
\hline 0.63 & 0.38 & 0.39 & 0.14 & 3.52 & 2.73 & 0.39 & 1.27 & 0.98 & 0.14 \\
\hline 0.50 & 0.50 & 0.25 & 0.25 & 2.50 & 1.00 & 0.25 & 2.50 & 1.00 & 0.25 \\
\hline 0.67 & 0.33 & 0.44 & 0.11 & 1.78 & 1.78 & 2.67 & 0.44 & 0.44 & 0.67 \\
\hline 0.71 & 0.29 & 0.51 & 0.08 & 1.53 & 2.04 & 4.59 & 0.24 & 0.33 & 0.73 \\
\hline 0.25 & 0.75 & 0.06 & 0.56 & 0.50 & 0.63 & 0.13 & 4.50 & 5.63 & 1.13 \\
\hline 0.36 & 0.64 & 0.13 & 0.40 & 1.06 & 0.93 & 0.79 & 3.24 & 2.83 & 2.43 \\
\hline 0.86 & 0.14 & 0.73 & 0.02 & 3.67 & 2.20 & 4.41 & 0.10 & 0.06 & 0.12 \\
\hline \multicolumn{2}{|c|}{ Jumlah } & 3.14 & 2.45 & 19.66 & 15.5 & 19.16 & 19.36 & 17.23 & 13.73 \\
\hline
\end{tabular}

Kemudian di setiap kolom $\left(\mu_{i 1}\right)^{w *} 0_{i 1},\left(\mu_{i 1}\right)^{w *} 0_{i 2}$, $\left(\mu_{i 1}\right)^{w *}{ }^{*}{ }_{i 3}$ merupakan perkalian antara matrik partisi yang sudah dipangkatkan oleh bobot tersebut kemudian dikalikan dengan dataset nilai akademis ataupun nilai perilaku atau sikap. Jadi hasil dari pusat cluster di partikel 1 adalah hasil dari penjumlahan total atau di excel menggunakan rumus "=SUM" di setiap kolom diatas dimana hasil akhirnya di bandingkan $\Sigma\left(\mu_{i 1}\right)^{w}{ }^{*} 0_{i 1} / \quad \Sigma\left(\mu_{i 1}\right)^{\mathrm{w}}$ menghasilkan $Z_{k 1}$ dibaris pertama dan $\Sigma\left(\mu_{i 1}\right)^{w *^{*}} \mathrm{O}_{i 1}$ / $\Sigma\left(\mu_{\mathrm{i} 2}\right)^{\mathrm{w}}$ dibaris kedua, dan seterusnya sehingga membentuk pusat cluster di setiap partisi. Penetuan pusat cluster inilah yang menjadikan sangat penting dan menjadikan optimasi PSO ini berjalan dan mempengaruhi fungsi objektif, nilai keanggotaan sehingga update partikel di iterasi berikutnya akan sangat berpengaruh di hasil pembagian cluster dan kinerja clustering.

Tabel 7. Hasil Pusat Cluster di Partikel 1

\begin{tabular}{|c|c|c|}
\hline \multicolumn{3}{|c|}{$P_{1}$} \\
\hline$Z_{k 1}$ & $Z_{k 2}$ & $Z_{k 3}$ \\
\hline 6.22 & 4.91 & 6.06 \\
\hline 7.88 & 2.46 & 5.58 \\
\hline
\end{tabular}

Perbedaannya di dalam penentuan pusat cluster antara Fuzzy C-Means dan PSO adalah menghitungnya pada matrik partisi di lakukan sampai beberapa partikel sesuai dengan namanya Particle Swarms Optimation dimana perhitunganya akan lebih memakan banyak waktu tetapi akan dapat menentukan dan menghasilkan pembagian cluster yang lebih baik.

Langkah selanjutnya setelah menemukan pusat cluster adalah menentukan nilai fungsi objektifnya di setiap partikel dimana kalau di Fuzzy C-Means hanya dilakukan satu kali perhitungan nilai fungsi objektif disetiap iterasi, tetapi di algoritma ini satu iterasi tentunya akan dihitung berberapa kali sesuai partikelnya.

Pada perhitungan fungsi objektif, nilai tiap anggota yang ada di variabel nilai dihitung selisihnya masing - masing dengan pusat clusternya kemudian dijumlahkan total kemudian dibagi dengan nilai matrik partisi yang sudah dipangkatkan dengan bobotnya. Maka akan dihasilkan nilai total fungsi objektif yang menyatakan total rata - rata hubungan jarak antar anggota dengan pusat cluster. Berikut merupakan perwakilan perhitungan fungsi objektif pada partikel pertama yang nantinya hasil dari semua perhitungan pusat cluster dan fungsi objektif disetiap partikel untuk mentukan pula nilai keanggotaan yang terkecil serta Pbest dan Gbestnya.

Tabel 8. Perhitungan Fungsi Objektif di Partikel 1

\begin{tabular}{|c|c|c|c|c|c|c|c|c|c|c|}
\hline \multicolumn{11}{|c|}{$P_{1}$} \\
\hline & & & \multicolumn{4}{|c|}{$k=1$} & \multicolumn{4}{|c|}{$k=2$} \\
\hline $\mathrm{O}_{i 1}$ & $\mathrm{O}_{\mathrm{i} 2}$ & $\mathrm{O}_{\mathrm{i}}$ & $\left(o_{i 1}-z_{11}\right)^{2}$ & $\left(o_{i 2}-z_{12}\right)^{2}$ & $\left(o_{i 3}-Z_{13}\right)^{2}$ & $J m l /\left(\mu_{i 1}\right)^{w}$ & $\left(o_{i 1}-O Z_{11}\right)^{2}$ & $\left(o_{i 2}-z_{12}\right)^{2}$ & $\left(o_{i 3}-z_{13}\right)^{2}$ & $\mathrm{Jml} /\left(\mu_{\mathrm{i} 2}\right)^{n}$ \\
\hline 7 & 7 & 10 & 0.60518 & 4.38499 & 15.48509 & 4.594172 & 0.77066 & 20.62755 & 19.49231 & 11.32701 \\
\hline 9 & 6 & 9 & 7.71692 & 1.19692 & 8.61487 & 4.382177 & 1.25917 & 12.54404 & 11.66229 & 6.366373 \\
\hline 8 & 7 & 9 & 3.16105 & 4.38499 & 8.61487 & 2.585746 & 0.01491 & 20.62755 & 11.66229 & 11.62971 \\
\hline 9 & 7 & 1 & 7.71692 & 4.38499 & 25.65312 & 14.74806 & 1.25917 & 20.62755 & 21.02214 & 6.034058 \\
\hline 10 & 4 & 1 & 14.27279 & 0.82077 & 25.65312 & 10.18667 & 4.50342 & 2.37701 & 21.02214 & 6.975643 \\
\hline 4 & 4 & 6 & 4.93757 & 0.82077 & 0.00421 & 2.561134 & 15.03791 & 2.37701 & 0.17223 & 1.954128 \\
\hline 3 & 4 & 9 & 10.38170 & 0.82077 & 8.61487 & 10.11089 & 23.79365 & 2.37701 & 11.66229 & 3.088404 \\
\hline
\end{tabular}




\begin{tabular}{|c|c|c|c|c|c|c|c|c|c|c|}
\hline 8 & 10 & 2 & 3.16105 & 25.94921 & 16.52334 & 2.8521 & 0.01491 & 56.87808 & 12.85216 & 39.23165 \\
\hline 8 & 7 & 6 & 3.16105 & 4.38499 & 0.00421 & 0.998381 & 0.01491 & 20.62755 & 0.17223 & 8.429092 \\
\hline 5 & 3 & 6 & 1.49344 & 3.63269 & 0.00421 & 3.769235 & 8.28216 & 0.29350 & 0.17223 & 0.178528 \\
\hline \multicolumn{6}{|c|}{ Jumlah } & 56.788565 & \multicolumn{3}{|c|}{ jumlah } & 95.214596 \\
\hline \multicolumn{11}{|c|}{ Fungsi objektif $=\mathbf{5 6 . 7 8 8 5 6 5}+\mathbf{9 5 . 2 1 4 5 9 6}=152.0032$} \\
\hline
\end{tabular}

Dalam implementasinya, ditemukan bahwa kecepatan partikel dalam PSO diupdate terlalu cepat dan nilai minimum fungsi tujuan sering terlewati. Karena itu ada revisi atau perbaikan terhadap algoritma PSO standard. Perbaikan itu berupa penambahan suatu inersia $\theta$ untuk mengurangi kecepatan. Pada ekperimen ini menggunakan bobot inersia 0,7 . Biasanya nilai $\theta$ dibuat sedemikian hingga semakin meningkat iterasi yang dilalui, semakin mengecil kecepatan partikel.

Pbest adalah partikel dengan fungsi keanggotaan terkecil, Untuk iterasi 1 Gbest sama dengan Pbest. Dari semua fungsi objektif pada perhitungan disetiap partikel di iterasi pertama menunjuk salah satu partikel matrik partisi dari nilai variabel akademis dan variabel sikap, yang kemudian akan di hitung untuk menentukan update posisi partikel dan velocity yang baru pada iterasi berikutnya.
Dimana $c 1$ dan $c 2$ masing-masing adalah learning rates untuk kemampuan individu (cognitive) dan pengaruh sosial (group), dan $r$ dan $r 2$ bilangan random yang berdistribusi uniforml dalam interval 0 dan 1 , dan pada penelitan ini penulis memakai nilai 0,5 . Jadi parameters $c 1$ dan $c 2$ dmenunjukkan bobot dari memory (position) sebuah partikel terhadap memory (posisi) dari kelompok (swarm). Nilai dari $c 1$ dan $c 2$ yang diberikan peneliti adalah adalah 2 sehingga perkalian $c 1 r$ dan $c 2 r 2$ memastikan bahwa partikel-partikel akan mendekati target sekitar setengah selisihnya.

Tabel 9. Perhitungan Update Posisi Partikel dan Velocity

\begin{tabular}{|c|c|c|c|c|c|c|c|c|c|c|c|}
\hline \multicolumn{2}{|c|}{$\mathbf{V}_{\mathbf{1}} \mathbf{A}$} & \multicolumn{2}{c|}{$\boldsymbol{\theta} \mathbf{V}_{\mathbf{1}} \mathbf{c}$} & \multicolumn{2}{c|}{$\mathbf{P}_{\text {best }}$} & \multicolumn{2}{c|}{$\mathbf{P}_{\mathbf{1}}$} & \multicolumn{2}{c|}{$\mathbf{p}_{\text {best }}-\mathbf{P}_{\mathbf{1}}$} & \multicolumn{2}{c|}{$\mathbf{c 1 r 1}\left(\mathbf{P}_{\text {best }}-\mathbf{P}_{\mathbf{1}}\right)$} \\
\hline 1.000 & 0.600 & 0.7 & 0.474 & 0.667 & 0.333 & 0.474 & 0.526 & 0.193 & -0.193 & 0.193 & -0.193 \\
\hline 0.800 & 0.100 & 0.56 & 0.500 & 0.222 & 0.778 & 0.500 & 0.500 & -0.278 & 0.278 & -0.278 & 0.278 \\
\hline 0.200 & 0.400 & 0.14 & 0.400 & 0.500 & 0.500 & 0.400 & 0.600 & 0.1 & -0.1 & 0.1 & -0.1 \\
\hline 0.700 & 0.300 & 0.49 & 0.625 & 0.750 & 0.250 & 0.625 & 0.375 & 0.125 & -0.125 & 0.125 & -0.125 \\
\hline 0.200 & 0.700 & 0.14 & 0.500 & 0.500 & 0.500 & 0.500 & 0.500 & 0 & 0 & 0 & 0 \\
\hline 1.000 & 0.500 & 0.7 & 0.667 & 0.563 & 0.438 & 0.667 & 0.333 & -0.104 & 0.105 & -0.104 & 0.105 \\
\hline 1.000 & 0.200 & 0.7 & 0.714 & 0.667 & 0.333 & 0.714 & 0.286 & -0.047 & 0.047 & -0.047 & 0.047 \\
\hline 0.100 & 0.900 & 0.07 & 0.250 & 0.438 & 0.563 & 0.250 & 0.750 & 0.188 & -0.187 & 0.188 & -0.187 \\
\hline 0.400 & 0.600 & 0.28 & 0.364 & 0.538 & 0.462 & 0.364 & 0.636 & 0.174 & -0.174 & 0.174 & -0.174 \\
\hline 0.700 & 0.700 & 0.49 & 0.857 & 0.500 & 0.500 & 0.857 & 0.143 & -0.357 & 0.357 & -0.357 & 0.357 \\
\hline
\end{tabular}

\begin{tabular}{|l|c|c|c|c|c|c|c|}
\hline \multicolumn{2}{|c|}{$\mathbf{g}_{\text {best }}$} & \multicolumn{2}{c|}{$\mathbf{g}_{\text {best }}-\boldsymbol{\mu}_{\mathbf{1}}$} & \multicolumn{2}{c|}{$\mathbf{c 2} 2 \mathbf{g}_{\text {best }}-\mathbf{P}_{\mathbf{1}} \mathbf{)}$} & \multicolumn{2}{c|}{$\mathbf{V}_{\mathbf{t + 1}}$} \\
\hline 0.667 & 0.333 & 0.193 & -0.193 & 0.193 & -0.193 & 1.086 & 0.034 \\
\hline 0.222 & 0.778 & -0.278 & 0.278 & -0.278 & 0.278 & 0.004 & 0.626 \\
\hline 0.500 & 0.500 & 0.1 & -0.1 & 0.1 & -0.1 & 0.340 & 0.080 \\
\hline 0.750 & 0.250 & 0.125 & -0.125 & 0.125 & -0.125 & 0.740 & -0.040 \\
\hline 0.500 & 0.500 & 0 & 0 & 0 & 0 & 0.140 & 0.490 \\
\hline 0.563 & 0.438 & -0.104 & 0.105 & -0.104 & 0.105 & 0.492 & 0.560 \\
\hline 0.667 & 0.333 & -0.047 & 0.047 & -0.047 & 0.047 & 0.606 & 0.234 \\
\hline 0.438 & 0.563 & 0.188 & -0.187 & 0.188 & -0.187 & 0.446 & 0.256 \\
\hline 0.538 & 0.462 & 0.174 & -0.174 & 0.174 & -0.174 & 0.628 & 0.072 \\
\hline 0.500 & 0.500 & -0.357 & 0.357 & -0.357 & 0.357 & -0.224 & 1.204 \\
\hline
\end{tabular}


Cek apakah solusi yang sekarang sudah konvergen. Jika posisi semua partikel menuju ke satu nilai yang sama, maka ini disebut konvergen. Jika belum konvergen maka langkah ini diulang dengan memperbarui iterasi $i=i+1$, dengan cara menghitung nilai baru dari Pbest,j dan Gbest. Proses iterasi ini dilanjutkan sampai semua partikel menuju ke satu titik solusi yang sama. Biasanya akan ditentukan dengan kriteria penghentian (stopping criteria), misalnya jumlah selisih solusi sekarang dengan solusi sebelumnya sudah sangat kecil.

Tabel 10. Hasil Update partikel dan velocity

\begin{tabular}{|c|c|c|c|c|c|}
\hline \multicolumn{5}{|c|}{$\mathrm{P}_{1}$} & \multicolumn{2}{c|}{$\mathrm{P}_{1}(\mathrm{t}+1)$} \\
\hline$\mu_{\mathrm{i} 1}$ & $\mu_{\mathrm{i} 2}$ & \multicolumn{2}{|c|}{$\mathrm{V}_{\mathrm{t}+1}$} & $\mu_{\mathrm{i} 1}$ & $\mu_{\mathrm{i} 2}$ \\
\hline 0.474 & 0.526 & 1.086 & 0.034 & $\mathbf{1 . 5 6}$ & $\mathbf{0 . 5 6}$ \\
\hline 0.500 & 0.500 & 0.004 & 0.626 & $\mathbf{0 . 5 0}$ & $\mathbf{1 . 1 3}$ \\
\hline 0.400 & 0.600 & 0.340 & 0.080 & $\mathbf{0 . 7 4}$ & $\mathbf{0 . 6 8}$ \\
\hline 0.625 & 0.375 & 0.740 & -0.040 & $\mathbf{1 . 3 7}$ & $\mathbf{0 . 3 4}$ \\
\hline 0.500 & 0.500 & 0.140 & 0.490 & $\mathbf{0 . 6 4}$ & $\mathbf{0 . 9 9}$ \\
\hline 0.667 & 0.333 & 0.492 & 0.560 & $\mathbf{1 . 1 6}$ & $\mathbf{0 . 8 9}$ \\
\hline 0.714 & 0.286 & 0.606 & 0.234 & $\mathbf{1 . 3 2}$ & $\mathbf{0 . 5 2}$ \\
\hline 0.250 & 0.750 & 0.446 & 0.256 & $\mathbf{0 . 7 0}$ & $\mathbf{1 . 0 1}$ \\
\hline 0.364 & 0.636 & 0.628 & 0.072 & $\mathbf{0 . 9 9}$ & $\mathbf{0 . 7 1}$ \\
\hline 0.857 & 0.143 & -0.224 & 1.204 & $\mathbf{0 . 6 3}$ & $\mathbf{1 . 3 5}$ \\
\hline
\end{tabular}

Nilai hasil angka yang keluar dari $P_{1}(t+1)$ yang merupakan perhitungan dari formula rumus persamaan (12) yang merupakan perbaikan dari rumus persamaan (9) yang telah mengalami perbaikan dengan penambaha bobot inesia $\theta$ akan dijadikan perhitungan untuk iterasi berikutnya dalam pemilihan pusat cluster dan tentunya pembagian clustering yang lebih baik serta iterasi yang lebih optimal performnya dibandingkan dengan formula rumus pada Fuzzy C-Means yang masih standart dalam perhitungannya tampa adanya perhitungan yang lebih detail di setiap partikel pada satu iterasi.

Hasil tabel diatas merupakan perwakilan dari satu perhitungan partikel disetiap iterasi yang memungkinkan bahwa nilai clustering akan menjadi lebih baik dan performa iterasi akan lebih baik apabila perhitungan algorima Fuzzy C-Means dioptimasi dengan PSO yang sangat berkontribusi dalam peningkatan nilai tersebut.

\subsection{Hasil Pembagian Cluster Kelas}

Pada penelitian ini telah diamati dari berbagai aspek termasuk diantaranya adalah hasil pembagian cluster dimana pada penelitian ini kelas untuk pembelajaran dibagi menjadi 3 cluster dimana cluster 1 adalah anak dengan kriteria baik, cluster 2 adalah anak dengan kriteria sedang dan yang ke 3 adalah anak dengan kriteria kurang. Dimana acuan tersebut adalah anak dengan nilai akademik dan nilai perilaku atau sikap yang pada kriteria tertentu.

Tabel 11. Pembagian rerata cluster

\begin{tabular}{|l|l|l|l|l|}
\hline Variabel & \multicolumn{2}{|l|}{ Nilai Akademis } & \multicolumn{2}{|c|}{$\begin{array}{c}\text { Nilai Akademis + } \\
\text { Perilaku atau Sikap }\end{array}$} \\
\hline Algoritma & FCM(A) & FCM+PSO(A) & FCM(B) & FCM+PSO(B) \\
\hline cluster 3 & 95 & 123 & 154 & 149 \\
\hline cluster 2 & 188 & 122 & 107 & 125 \\
\hline Cluster 1 & 120 & 158 & 142 & 129 \\
\hline
\end{tabular}

Pada eksperimen ini dibagi menjadi 4 metode tahap penelitian untuk membandingkan hasil cluster yang terbaik selain dari nilai index validitas cluster. Eksperimen yang pertama adalah metode clustering FCM dengan variabel nilai akademis saja $\operatorname{FCM}(A)$ yang menunjukkan pembagian kelas yang kurang merata dimana kelas anak yang berkriteria sedang mendapatkan angka 188 lebih besar dari kelas lainnya yang hanya 95 berkriteria baik dan 120 berkriteria kurang.

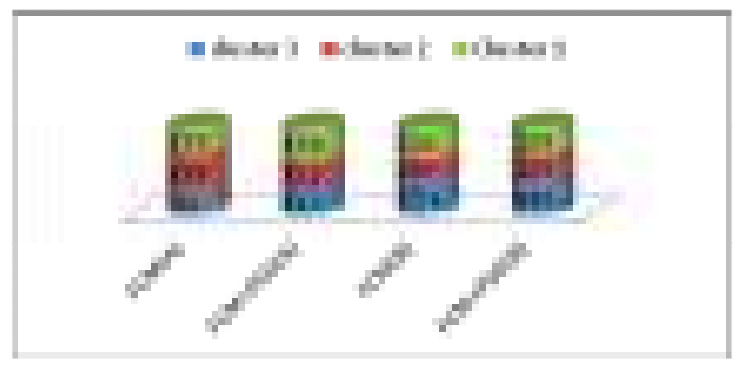

Gambar 2. Grafik pembagian rerata cluster

Berikutnya adalah dengan optimasi PSO di grafik $\mathrm{FCM}+\mathrm{PSO}(\mathrm{A})$ pada variabel yang sama menunjukkan rerata yang lebih seimbang, bisa dilihat pada nilai terbesarnya 158 anak adalah pada cluster 1, sisanya adalah 122 anak pada cluster 2 dan 123 anak pada cluster 3 yaitu pada iterasi ke 14. Lebih cepat dan lebih bagus apabila menggunakan optimasi PSO berbeda dengan clustering FCM saja yang mencapai nilai index validitas baik pada iterasi ke 37 .

Eksperimen berikutnya $\mathrm{FCM}(\mathrm{B})$ dalam pembagian kelasnya adalah penelitian dengan metode FCM pada variabel akademik dan variabel perilaku atau sikap yang terlihat pada gambar 4.8 dimana ketiga clusternya dibagi secara hampir seimbang dengan rerata pada iterasi ke 34 menunjukkan pembagian yang seimbang yaitu 142 pada cluster 1 dan 154 pada cluster 3, sedangkan 107 pada cluster 2 .

Yang terakhir adalah pada grafik $\mathrm{FCM}+\mathrm{PSO}(\mathrm{B})$ pada penelian dengan optimasi PSO dengan variabel akademik dan variabel perilaku atau sikap, rerata yang dihasilkan juga seimbang di cluster 1 dan cluster 2 yaitu sebesar 129 dan 125 dan lebih besar sedikit yaitu 149 yang dapat diselesaikan pada iterasi ke 13, dimana iterasi ini paling cepat diantara semua ekperimen yang lain.

\subsection{Informasi Pembagian Kelas}

Didalam pengelompokan kelas yang menjadi acuannya adalah variabel nilai akademis dan nilai perilaku atau sikap yang dihasilkan tentunya akan membagi beberapa kelompok siswa yang tentunya mempunyai kelompok yang hampir sama karakteristik nilainya. Metode clustering merupakan 
suatu model algoritma yang tak terbimbing atau tampa label dan tentunya informasi yang diperoleh dari hasil clusteringnya merupakan hasil informasi yang baru.

\subsubsection{Informasi Clustering FCM pada Nilai Akademis}

Dalam analisis ini selain informasi yang sudah didapatkan oleh hasil validitas cluster dan informasi pembagian yang ada didalamnya akan dianalisi satu persatu bagaimanakan nilai itu tersebar di beberapa cluster kelompok belajar siswa tersebut yang terdiri dari kelompok anak dengan kriteria baik di cluster 3 , anak dengan kriteria sedang di cluster 2 dan anak dengan kriteria kurang di cluster 1. Dan itu bukan merupakan suatu label dan masih bisa berubah ubah untuk kriterianya. Yang pertama adalah hasil pembagian clustering di algoritma Fuzzy C-Means yang membagi kelas berdasarkan nilai akademik.

Tabel 12. Hasil Pembagian Clustering FCM di Nilai Akademik

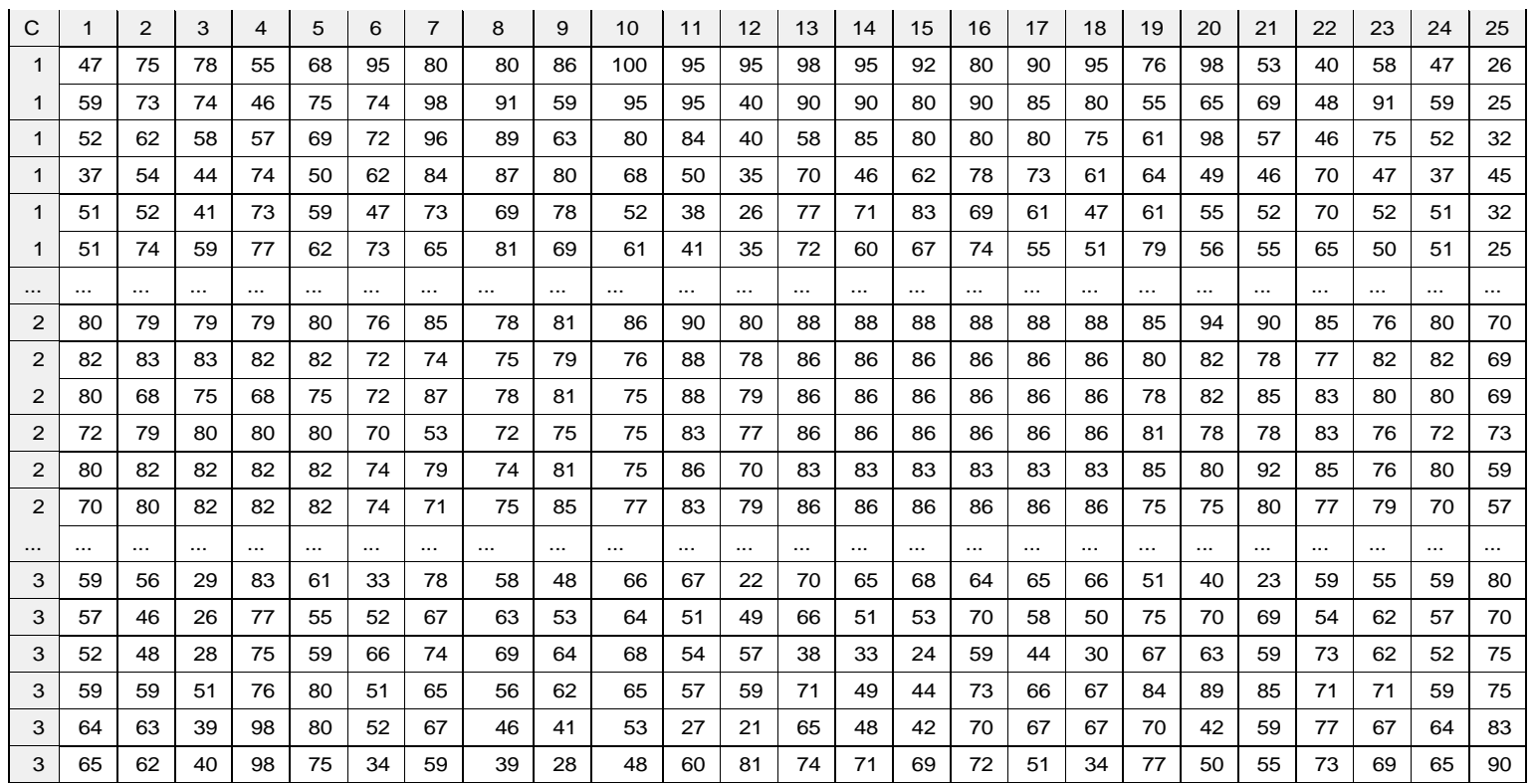

Dari tabel diatas terlihat bahwa pembagian nilai anak masih terlihat acak dan pengaruh dari beberapa variabel nilai akademis masih mengumpulkan nilai siswa di nilai yang pada cluster 2 adalah nilai siswa yang tinggi pada beberapa nilai normatifnya dan pada nilai produktifnya. Adapun pergeran nilainya tidak terlalu jauh pada nilai adaptif yang turun sedikit sekali dan diikuti dengan nilai muatan lokal yang baik.

Sementara di cluster 1 dan cluster 2 masih bercampurnya nilai anak pada kriteria sedang dan anak dengan kriteria kurang. Bahkan pada cluster pertama ada siswa yang yang mempunyai satu nilai tertinggi di nilai normatifnya tapi di nilai yang lain kurang. Meskipun ada nilai yang tinggi di beberapa nilai bahkan paling tinggi, tetapi karena ada banyak nilai yang masih kurang algoritma ini menaruhnya di cluster 1 atau kelompok kelas dengan nilai kurang.

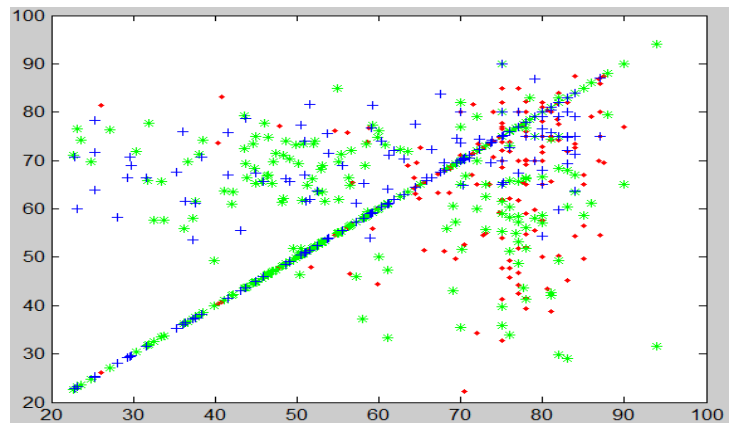

Gambar 13. Grafik persebaran clustering FCM pada Nilai Akademis

Hasil dari gambar histogram berikut juga menunjukkan bahwa clustering pada eksperiment di awal ini masih teracak dimana warna biru merah dan hijau masih berbaur menjadi satu di derajat keanggotaan yang sama yang menunjukkan derajat keanggotaan naik dan sistem fuzzy di metode clustring ini justru menjadikan kelompok anggota masih kabur dalam bergabung di cluster lain seperti yang terlihat digambar dimana posisi diatas di tengah maupun di bawah masih di dominasi beberapa warna. 


\subsubsection{Informasi Clustering FCM+PSO pada Nilai Akademis}

Pada eksperiment yang kedua masih pada variabel nilai akademis, tetapi sudah menggunakan optimasi PSO dan terlihat di tabel dibawah ini pembagian sudah dirasa sudah baik di setiap pembagian kelasnya dimana anak yang miliki karakteristik nilai yang kurang sudah berkumpul di cluster satu dimana anak dengan nilai - nilai yang sedikit disetiap mata pelajaranya. Selain itu di cluster yang ke dua merupakan nilai anak - anak yang memiliki nilai sedang meskipun ada nilai yang tinggi di beberapa mata pelajaran ataupun yang rendah tetapi rentangnya tidak terlalu jauh dan diikuti pula dengan nilai teman temannya yang sama di setiap mata pelajaran yang sama. Ini menunjukkan bahwa pengelompokan dengan optimasi PSO berhasil dan membentuk polanya sendiri.

Tabel 14. Hasil Pembagian Clustering FCM+PSO di Nilai Akademik

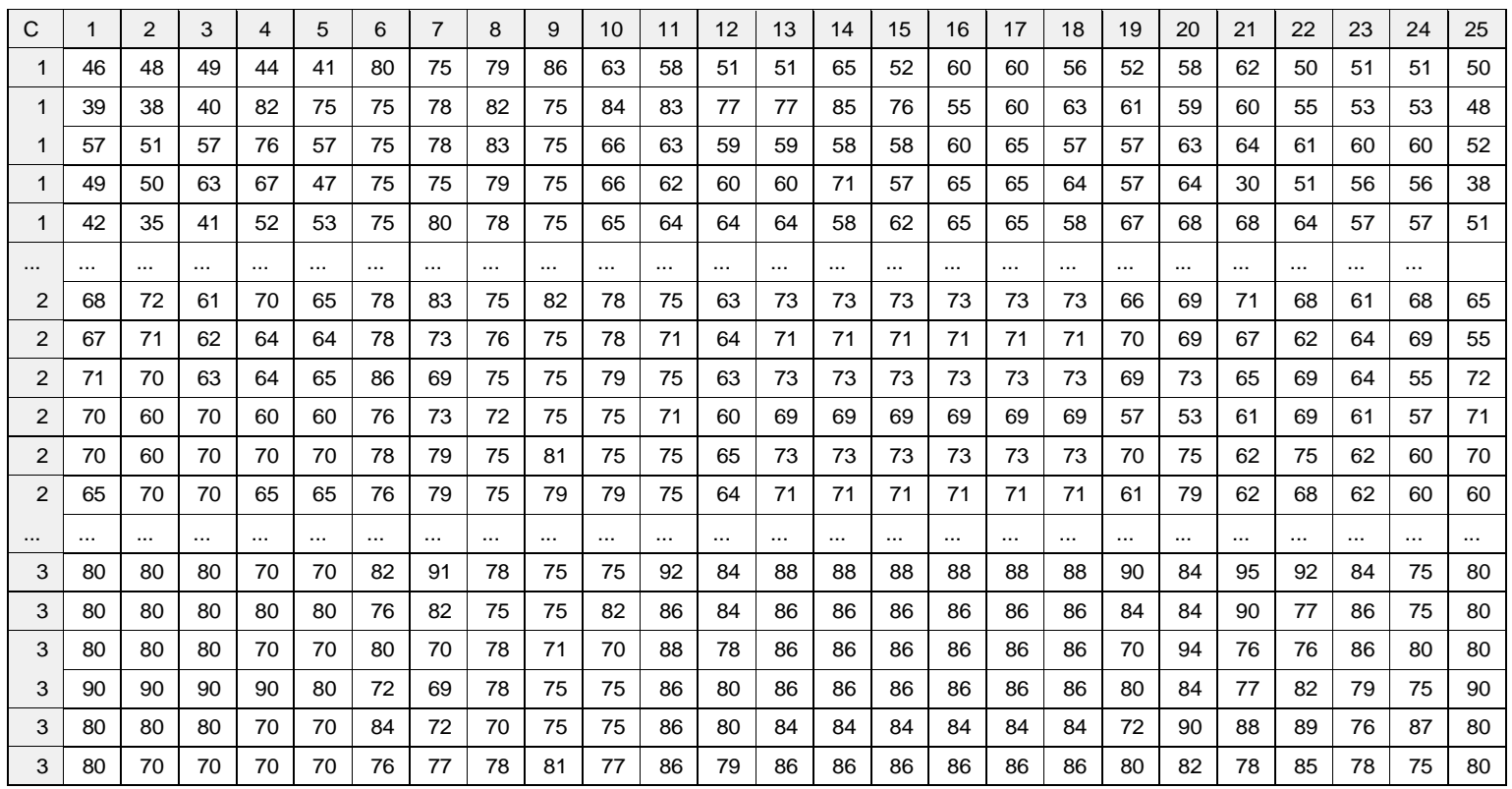

Memang tidak bisa dipungkiri jika pembagian cluster pada ekserimen ini meskipun sudah menggunakan optimasi tetapi masih ada beberapa nilai yang masih agak bias dikarenakan memang seperti itulah datanya. Seperti contoh pada tabel dia atas nilai muatan lokal pada cluster 1 dan cluster 2 hampir sama nilai kelompoknya. Meskipun demikian telah bisa memilahnya di nilai adaptif, normatif dan produktif yang memiliki karakteristik yang sudah terpisah - pisah dengan baik, bahkan di cluster 3 yang menyatakan nilai dengan karakteristik baik memang memperoleh nilai tinggi di setiap nilai mata pelajaran.

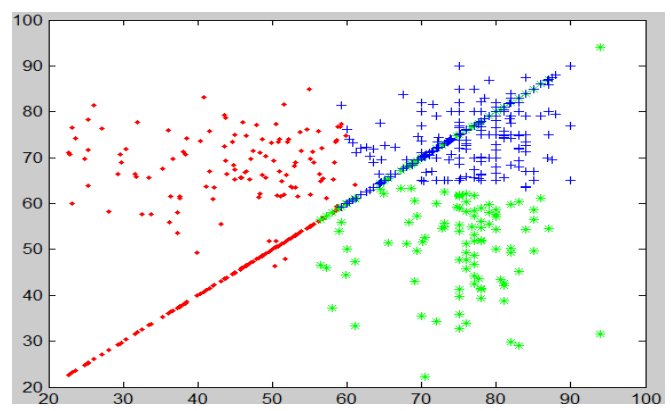

Gambar 5. Grafik persebaran clustering FCM+PSO pada Nilai Akademis
Hasil dari gambar histogram diatas menunjukkan optimasi PSO telah membagi titik data pada lokasinya sudah terpisah dengan baik meskipun ada beberapa titik yang masih membaur seperti titik biru dan titik hijau dimana pada derajat keanggotaan naik tersebut masih ada beberapa data yang masih kabur masuk ke cluster mana. Titik merah pada posisi nilai terendah juga tidak begitu banyak berbaut dengan titik dengan warna lain.

\subsection{Informasi Clustering FCM pada Nilai Akademis dan Sikap}

Pada eksperimen yang ketiga metode clustering memakai algoritma Fuzzy C-Means dengan variabel yang dipakai adalah semau nilai akademis dan nilai perlaku atau sikap yang digunakan untuk mengelompokkan kelas. Ini menjadi sangat berat dan kompleks dalam mengclusternya terlihat bahwa pada perbandingan validitas clusternya yang kurang begitu bagus dan lama prosesnya juga menjadi lama. Tentunya hasil dari informasi pembagian atau pengelempokan kelas pada tiap cluster masih banyak yang kabur dan keteracakannya masih sangat tinggi. 
Tabel 15. Hasil Pembagian Clustering FCM di Nilai Akademik dan Perilaku/Sikap

\begin{tabular}{|c|c|c|c|c|c|c|c|c|c|c|c|c|c|c|c|c|c|c|c|c|c|c|c|c|}
\hline C & 1 & 2 & 3 & 4 & 5 & 6 & 7 & 8 & 9 & 10 & 11 & 12 & 13 & 14 & 15 & 16 & 17 & 18 & 19 & 20 & 21 & 22 & 23 & 24 \\
\hline 1 & 70 & 44 & 36 & 62 & 75 & 42 & 66 & 45 & 41 & 67 & 54 & 38 & 65 & 60 & 51 & 75 & 62 & 49 & 63 & 69 & 66 & 76 & 63 & 68 \\
\hline 1 & 67 & 49 & 41 & 52 & 75 & 25 & 59 & 43 & 34 & 59 & 51 & 41 & 68 & 62 & 63 & 68 & 56 & 51 & 71 & 71 & 68 & 71 & 49 & 42 \\
\hline 1 & 66 & 48 & 31 & 67 & 76 & 50 & 74 & 62 & 48 & 71 & 58 & 61 & 79 & 73 & 68 & 76 & 65 & 57 & 81 & 62 & 49 & 73 & 55 & 44 \\
\hline 1 & 63 & 50 & 39 & 98 & 80 & 52 & 67 & 46 & 41 & 53 & 27 & 21 & 65 & 48 & 42 & 70 & 67 & 67 & 70 & 42 & 59 & 77 & 67 & 64 \\
\hline$\ldots$ & $\ldots$ & $\ldots$ & $\ldots$ & $\ldots$ & $\ldots$ & $\ldots$ & $\ldots$ & $\ldots$ & $\ldots$ & $\ldots$ & $\ldots$ & $\ldots$ & $\ldots$ & $\ldots$ & $\ldots$ & $\ldots$ & $\ldots$ & $\ldots$ & $\ldots$ & $\ldots$ & $\ldots$ & $\ldots$ & $\ldots$ & $\ldots$ \\
\hline 2 & 71 & 68 & 66 & 42 & 92 & 60 & 56 & 51 & 35 & 62 & 47 & 52 & 73 & 74 & 73 & 72 & 50 & 45 & 73 & 71 & 62 & 43 & 35 & 23 \\
\hline 2 & 70 & 48 & 68 & 59 & 87 & 80 & 66 & 60 & 49 & 68 & 66 & 61 & 63 & 64 & 55 & 64 & 47 & 46 & 67 & 71 & 74 & 57 & 44 & 37 \\
\hline 2 & 77 & 56 & 58 & 52 & 85 & 71 & 56 & 51 & 40 & 59 & 44 & 35 & 57 & 52 & 43 & 56 & 58 & 43 & 42 & 30 & 22 & 51 & 40 & 23 \\
\hline$\ldots$ & $\ldots$ & $\ldots$ & $\ldots$ & $\ldots$ & $\ldots$ & $\ldots$ & $\ldots$ & $\ldots$ & $\ldots$ & $\ldots$ & $\ldots$ & $\ldots$ & $\ldots$ & $\ldots$ & $\ldots$ & $\ldots$ & $\ldots$ & $\ldots$ & $\ldots$ & $\ldots$ & $\ldots$ & $\ldots$ & $\ldots$ & $\ldots$ \\
\hline 3 & 90 & 90 & 90 & 90 & 80 & 72 & 69 & 78 & 75 & 75 & 86 & 80 & 86 & 86 & 86 & 86 & 86 & 86 & 80 & 84 & 77 & 82 & 79 & 75 \\
\hline 3 & 80 & 80 & 80 & 70 & 70 & 84 & 72 & 70 & 75 & 75 & 86 & 80 & 84 & 84 & 84 & 84 & 84 & 84 & 72 & 90 & 88 & 89 & 76 & 87 \\
\hline 3 & 80 & 80 & 80 & 80 & 70 & 76 & 76 & 70 & 83 & 77 & 90 & 79 & 88 & 88 & 88 & 88 & 88 & 88 & 82 & 76 & 84 & 78 & 84 & 74 \\
\hline 3 & 90 & 90 & 90 & 80 & 80 & 70 & 84 & 75 & 83 & 85 & 88 & 79 & 86 & 86 & 86 & 86 & 86 & 86 & 88 & 88 & 86 & 88 & 86 & 75 \\
\hline 3 & 80 & 80 & 70 & 70 & 70 & 74 & 80 & 80 & 77 & 86 & 86 & 79 & 88 & 88 & 88 & 88 & 88 & 88 & 90 & 82 & 88 & 85 & 88 & 75 \\
\hline 3 & 80 & 70 & 70 & 70 & 70 & 78 & 86 & 80 & 89 & 83 & 90 & 87 & 88 & 88 & 88 & 88 & 88 & 88 & 86 & 84 & 84 & 80 & 84 & 80 \\
\hline
\end{tabular}

\begin{tabular}{|r|l|l|l|l|l|l|}
\hline C & 25 & 26 & 27 & 28 & 29 & 30 \\
\hline 1 & 59 & 81 & 68 & 65 & 60 & 49 \\
\hline 1 & 71 & 67 & 53 & 67 & 87 & 46 \\
\hline 1 & 72 & 73 & 51 & 68 & 78 & 52 \\
\hline 1 & 73 & 63 & 52 & 48 & 82 & 49 \\
\hline 1 & 68 & 70 & 36 & 62 & 75 & 42 \\
\hline 1 & 65 & 73 & 40 & 98 & 78 & 41 \\
\hline$\ldots$ & $\ldots$ & $\ldots$ & $\ldots$ & $\ldots$ & $\ldots$ & $\ldots$ \\
\hline 2 & 44 & 73 & 74 & 98 & 80 & 55 \\
\hline 2 & 56 & 76 & 74 & 79 & 80 & 34 \\
\hline 2 & 45 & 65 & 50 & 98 & 85 & 24 \\
\hline 2 & 60 & 74 & 60 & 99 & 90 & 66 \\
\hline 2 & 45 & 75 & 44 & 97 & 82 & 64 \\
\hline 2 & 32 & 78 & 51 & 98 & 78 & 67 \\
\hline$\ldots$ & $\ldots$ & $\ldots$ & $\ldots$ & $\ldots$ & $\ldots$ & $\ldots$ \\
\hline 3 & 73 & 55 & 55 & 65 & 55 & 74 \\
\hline 3 & 80 & 50 & 60 & 55 & 50 & 86 \\
\hline 3 & 85 & 65 & 65 & 70 & 60 & 84 \\
\hline 3 & 81 & 42 & 47 & 39 & 43 & 75 \\
\hline 3 & 85 & 59 & 57 & 47 & 38 & 75 \\
\hline 3 & 86 & 61 & 63 & 55 & 42 & 75 \\
\hline & & & & \\
\hline
\end{tabular}

Banyak nilai angka yang rata disemua cluster dan masih terkelompokan dengan pola yang kurang begitu bagus. Pada tabel diatas terlihat bahwa penambahan variabel nilai perilaku atau sikap mengubah pola data yang sebelumnya. Terlihat bahwa nilai perilaku atau sikap berusaha membentuk pola yang sama, tetapi dikarenakan berhubungan dengan variabel nilai perilaku atau sikap menjadikan pola pada setiap cluster hanya terbentuk beberapa yang hampir sama.

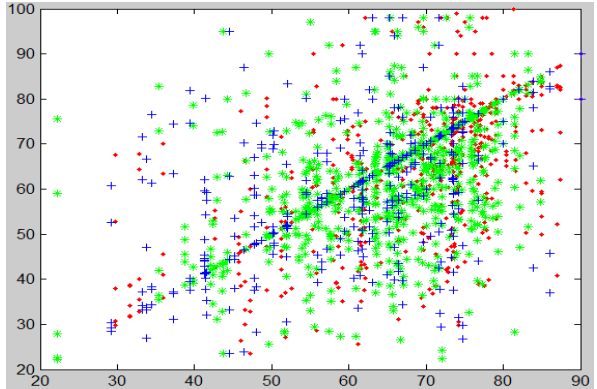

Gambar 6. Grafik persebaran clustering FCM pada Nilai Akademis+Sikap

Hasil dari gambar histogram diatas juga masih menunjukkan bahwa clustering pada eksperiment ketiga ini sama dengen di awal yaitu masih teracak dimana warna biru merah dan hijau masih berbaur menjadi satu di derajat keanggotaan yang sama yang menunjukkan derajat keanggotaan naik dan sistem fuzzy di metode clustring ini justru menjadikan kelompok anggota masih kabur dalam bergabung di cluster lain seperti yang terlihat digambar dimana posisi diatas di tengah maupun di bawah masih di dominasi beberapa warna. Perlu adanya optimasi yang memungkinkan menghandle data yang sengat banyak sampai 30 variabel nilai.

\section{Informasi Clustering FCM+PSO pada Nilai Akademis dan Sikap}

Pada eksperiment yang terakhir, semua variabel yaitu nilai akademis dan nilai perilaku atau sikap di cluster dengan algoritma Fuzzy C-Means yang telah dioptimasi dengan algoritma PSO. Terlihat di tabel dibawah ini pembagian sudah dirasa sudah baik di setiap pembagian kelasnya dimana anak yang memiliki karakteristik nilai yang kurang sudah berkumpul di cluster satu dimana 
anak dengan nilai - nilai yang sedikit disetiap mata pelajaranya. Selain itu di cluster yang ke dua merupakan nilai anak - anak yang memiliki nilai sedang meskipun ada nilai yang tinggi di beberapa mata pelajaran ataupun yang rendah tetapi rentangnya tidak terlalu jauh dan diikuti pula dengan nilai teman temannya yang sama di setiap mata pelajaran yang sama. Ini menunjukkan bahwa pengelompokan dengan optimasi PSO berhasil dan membentuk polanya sendiri, sama seperti di eksperiment kedua algoritma Fuzzy C-Means akan lebih bagus pengelompokanya apabila mendapatkan optimasi.

Tabel 17. Hasil Pembagian Clustering FCM+PSO di Nilai Akademik dan Perilaku/Sikap

\begin{tabular}{|c|c|c|c|c|c|c|c|c|c|c|c|c|c|c|c|c|c|c|c|c|c|c|c|c|}
\hline$C$ & 1 & 2 & 3 & 4 & 5 & 6 & 7 & 8 & 9 & 10 & 11 & 12 & 13 & 14 & 15 & 16 & 17 & 18 & 19 & 20 & 21 & 22 & 23 & 24 \\
\hline 1 & 56 & 76 & 74 & 79 & 80 & 34 & 58 & 37 & 34 & 68 & 62 & 73 & 59 & 49 & 38 & 71 & 75 & 80 & 68 & 62 & 79 & 63 & 61 & 56 \\
\hline 1 & 45 & 65 & 50 & 98 & 85 & 24 & 72 & 66 & 53 & 75 & 74 & 69 & 61 & 54 & 48 & 70 & 80 & 60 & 65 & 74 & 56 & 63 & 50 & 45 \\
\hline 1 & 45 & 75 & 44 & 97 & 82 & 64 & 53 & 56 & 56 & 58 & 50 & 46 & 74 & 60 & 51 & 81 & 59 & 46 & 57 & 62 & 54 & 62 & 52 & 45 \\
\hline 1 & 32 & 78 & 51 & 98 & 78 & 67 & 40 & 48 & 58 & 67 & 62 & 73 & 66 & 49 & 42 & 77 & 54 & 49 & 73 & 51 & 45 & 66 & 51 & 32 \\
\hline 1 & 25 & 72 & 42 & 98 & 92 & 70 & 58 & 40 & 35 & 68 & 53 & 45 & 62 & 49 & 43 & 74 & 58 & 53 & 77 & 57 & 40 & 54 & 41 & 25 \\
\hline 2 & 70 & 52 & 29 & 28 & 57 & 43 & 80 & 75 & 72 & 74 & 69 & 70 & 72 & 67 & 68 & 63 & 64 & 51 & 56 & 68 & 74 & 64 & 67 & 70 \\
\hline 2 & 69 & 50 & 44 & 26 & 90 & 58 & 70 & 67 & 69 & 71 & 57 & 52 & 76 & 66 & 68 & 70 & 69 & 63 & 76 & 62 & 65 & 76 & 74 & 69 \\
\hline 2 & 69 & 57 & 58 & 28 & 92 & 45 & 69 & 63 & 67 & 79 & 56 & 54 & 71 & 61 & 63 & 72 & 74 & 51 & 72 & 60 & 47 & 74 & 67 & 69 \\
\hline 2 & 73 & 54 & 35 & 81 & 64 & 60 & 69 & 49 & 49 & 74 & 69 & 63 & 74 & 66 & 68 & 80 & 90 & 90 & 78 & 64 & 47 & 69 & 66 & 73 \\
\hline 2 & 67 & 63 & 49 & 60 & 82 & 48 & 71 & 59 & 67 & 65 & 53 & 48 & 69 & 61 & 56 & 70 & 57 & 65 & 62 & 55 & 51 & 73 & 68 & 67 \\
\hline 3 & 82 & 83 & 83 & 82 & 82 & 82 & 84 & 85 & 89 & 86 & 98 & 88 & 96 & 90 & 90 & 96 & 96 & 96 & 80 & 82 & 78 & 77 & 82 & 82 \\
\hline 3 & 80 & 68 & 75 & 68 & 75 & 82 & 97 & 88 & 91 & 85 & 98 & 89 & 90 & 96 & 96 & 100 & 96 & 96 & 78 & 82 & 85 & 83 & 80 & 80 \\
\hline 3 & 80 & 82 & 82 & 82 & 82 & 80 & 63 & 82 & 85 & 85 & 93 & 87 & 90 & 96 & 90 & 96 & 96 & 96 & 85 & 80 & 92 & 85 & 76 & 80 \\
\hline 3 & 83 & 82 & 83 & 82 & 83 & 84 & 89 & 84 & 91 & 85 & 96 & 80 & 93 & 93 & 93 & 93 & 93 & 93 & 78 & 82 & 92 & 90 & 80 & 83 \\
\hline 3 & 90 & 77 & 70 & 77 & 72 & 84 & 81 & 85 & 95 & 87 & 100 & 89 & 96 & 96 & 96 & 96 & 96 & 96 & 92 & 96 & 95 & 93 & 78 & 90 \\
\hline
\end{tabular}

\begin{tabular}{|r|c|c|c|c|c|c|}
\hline $\mathrm{C}$ & 25 & 26 & 27 & 28 & 29 & 30 \\
\hline 1 & 54 & 33 & 27 & 60 & 51 & 57 \\
\cline { 2 - 7 } 1 & 49 & 57 & 66 & 59 & 50 & 58 \\
\hline 1 & 48 & 54 & 51 & 61 & 48 & 53 \\
\hline 1 & 57 & 32 & 25 & 63 & 44 & 50 \\
\cline { 2 - 6 } 1 & 56 & 48 & 47 & 67 & 52 & 63 \\
\hline 1 & 57 & 59 & 58 & 63 & 48 & 60 \\
\hline$\ldots$ & $\ldots$ & $\ldots$ & $\ldots$ & $\ldots$ & $\ldots$ & $\ldots$ \\
\hline 2 & 78 & 72 & 89 & 73 & 71 & 66 \\
\hline 2 & 75 & 84 & 66 & 73 & 60 & 55 \\
\hline 2 & 77 & 65 & 75 & 75 & 58 & 36 \\
\hline 2 & 80 & 70 & 69 & 62 & 51 & 35 \\
\hline 2 & 85 & 69 & 69 & 65 & 51 & 42 \\
\hline 2 & 67 & 57 & 57 & 88 & 77 & 75 \\
\hline$\ldots$ & $\ldots$ & $\ldots$ & $\ldots$ & $\ldots$ & $\ldots$ & $\ldots$ \\
\hline 3 & 88 & 85 & 90 & 96 & 88 & 83 \\
\hline 3 & 99 & 96 & 100 & 98 & 89 & 90 \\
\hline 3 & 95 & 100 & 89 & 95 & 89 & 95 \\
\hline 3 & 88 & 102 & 92 & 85 & 92 & 82 \\
\hline 3 & 90 & 95 & 95 & 95 & 95 & 91 \\
\cline { 2 - 6 } 3 & 88 & 93 & 92 & 92 & 92 & 95 \\
\hline & & & & \\
\hline
\end{tabular}

Pembagian cluster pada ekserimen ini meskipun sudah menggunakan optimasi tetapi masih ada beberapa nilai yang masih agak bias dikarenakan memang seperti itulah datanya, ditambah lagi semakin banyaknya variable nilai yang menentukan kriteria pembagian kelas menjadi semakin kompleks. Pada tabel diatas pada aspek nilai perilaku atau sikap kolom 26 sampai 30 menunjukkan pengelompokan nilai yang bagus dan membentuk pola, sehinnga sudah terpisah sendiri antara nilai yang tinggi, sedang dan kurang. Meskipun demikian pada nilai adaptif, normatif dan produktif nilainya agak sedikit berbaur antara cluster tapi sudah menunjukkan pembagian rerata pola yang sudah terpisah pisah yang bahkan di cluster 3 yang menyatakan nilai dengan karakteristik baik memang memperoleh nilai tinggi di setiap nilai mata pelajaran, yang hampir sama dengan eksperimen kedua. Pola yang terbentuk adalah nilai variabel perilaku atau sikap dengan nilai normatifnya relatif sudah terpisah dengan baik.

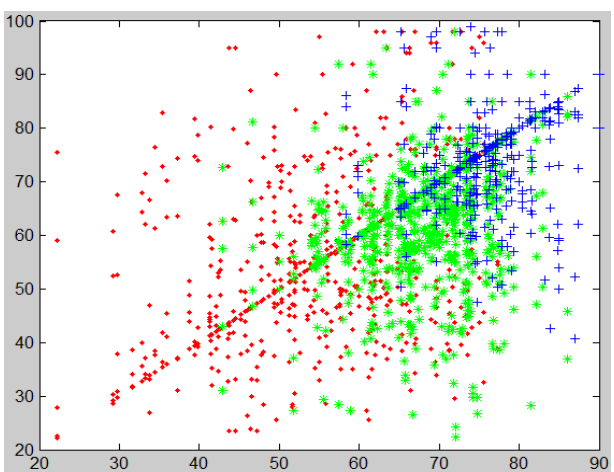

Gambar 7. Grafik persebaran clustering FCM+PSO pada Nilai Akademis+Sikap 
Hasil dari gambar histogram diatas menunjukkan optimasi PSO telah membagi titik data pada lokasinya sudah terpisah dengan baik meskipun ada beberapa titik yang masih membaur seperti titik biru dan titik hijau dimana pada derajat keanggotaan naik tersebut masih ada beberapa data yang masih kabur masuk ke cluster mana. Penambahan banyaknya titik yang menunjukkan data variabel yang semakin banyak pula bisa diatasi dengan optimasi ini dengan menunjukkan perbedaan pada eksperiment yang ketiga dimana masih berbaur.

Pada hakikatnya pengelompokan ini pada akhirnya tidak hanya mengelompokkan hanya pada nilai yang bagus pada semua nilai akademis saja, tetapi anak yang mempunyai nilai akademis yang kurang baik bisa masuk dengan melihat nilai perilaku atau sikap yang tinggi dan sebaliknya pula. Ini bisa dilihat pada grafik persebaran nilai yang cenderung linier naik pada semua hasil eksperimen.

\section{KESIMPULAN DAN SARAN / REKOMENDASI}

\subsection{Kesimpulan}

Pada awal hingga akhir penelitian Optimasi PSO Untuk Metode Clustering Fuzzy C-Means Dalam Pengelompokan Kelas dengan variabel nilai akademik dan variabel nilai perilaku atau sikap diperoleh beberapa kesimpulan, yaitu sebagai berikut :

1. Penelitian menggunakan variabel nilai akademik dengan metode clustering FCM yang dioptimasi dengan PSO menunjukkan peningkatan nilai yang lebih bagus dalam semua index validitas cluster serta meminimalkan iterasi, sehingga optimasi ini telah terbukti berhasil membentuk kelas cluster yang lebih kompak dari metode FCM. Lama prosesnya masih cepat pada metode FCM tampa optimasi PSO seperti penelitian yang terdahulu.

2. Penelitian menggunakan variabel nilai akademik dengan penambahan variabel nilai perilaku atau sikap menunjukkan nilai yang lebih baik disemua index validitas cluster, dibandingkan hanya memakai variabel nilai akademik saja. Ini memunjukkan bahwa nilai perilaku atau sikap juga penting digunakan untuk pembagian cluster kelas dalam pembelajaran.

3. Persebaran dalam pembagian cluster kelas pembelajaran dalam penelitian ini menunjukkan pembagian kelas yang seimbang dalam rasio jumlah peserta didik maupun dalam tingkat kecerdasan yang ditunjukan dengan variabel akademik dan sikap yang ditunjukan pada variabel nilai perilaku atau sikap akan lebih kompak.

4. Optimasi PSO dapat mengatasi kelemahan yang sering terjebak pada local optima dan pemilihan pusat cluster pada metode clustering Fuzzy C-Means yang terbukti dapat meningkatkan nilai index validitas cluster yang lebih baik di PCI, PEI, MPCI, FSI XBI, PCAESI. Meskipun tidak terlihat signifikan pada penambahan variabel nilai perilaku atau sikap.

\subsection{Saran / Rekomendasi}

Perbaikan serta pengembangan sangat diperlukan agar penelitian selanjutnya memberikan hasil yang lebih baik dari penelitian sebelumnya. Saran yang dapat diberikan untuk penelitian selanjutnya mengenai optimasi PSO terhadap metode Fuzzy C-Means Clustering adalah :

1. Menggabungkan dengan metode clustering yang lain agar dapat diketahui perbandingan dan hasil validitas cluster yang lebih baik ataupun yang terbaik.

2. Optimasi dapat dilakukan selain pada pemilihan pusat awal cluster, sehingga dapat mengetahui kemungkinan yang terjadi

Hasil dari pengelompokan kelas dengan metode clustering yang telah di optimasi ini dapat membantu atau dijadikan rekomendasi kepada pihak sekolah yang berwenang untuk diimplementasikan pada SMK tersebut dalam hal ini jurusan TKJ, serta bisa di implementasikan untuk sekolah yang lain untuk peningkatan kualitas belajar.

\section{DAFTAR PUSTAKA}

1. M. Fahim, A. M. Salem, F. A. Torkey and M. A. Ramadan, 2006, "An Efficient enhanced KMeansclustering algorithm", journal of Zhejiang University, 10(7): 16261633

2. Arikunto, Suharsimi, 2009. "Dasar-Dasar Evaluasi Pendidikan". Jakarta : Bumi Aksara

3. Franki Yusuf Bisilisin, Yeni Herdiyeni, Bib Paruhum Silalahi, "K-Means Clustering Optimization Using Particle Swarm Optimization On Image Based Medicinal Plant Identification System", Jurnal IImu Komputer Agri-Informatika, Vol 3 Nomor 1 hal 38-47

4. G. Komarasamy and Amitabh Wahi, 2011, "Improving th Cluster Performance by Combining PSO and K-Means Algorithm", Ictact Journal Soft Computing (IJSC), Volume: 01 ,

5. Hesam Izakian, Ajith Abraham 2009 "Fuzzy Clustering Using Hybrid Fuzzy c-means andFuzzy Particle SwarmOptimization" Czech Republic :VSB-Technical University of Ostrava Ostrava,IEEE

6. J. Kennedy and R. Eberhart. "Swarm Intelligence", 2001, Morgan Kaufmann Publishers, Inc., San Fransisco, CA

7. Lekshmy $\mathrm{P}$ Chandran,K A Abdul Nazeer, 2011, "An Improved Clustering Algorithm based on K-Means and Harmony Search Optimization", IEEE

8. Margono, 2000"Metodologi Penelitian Pendidika".Jakarta: Rineka Cipta

9. Mulyasa, 2005. "Menjadi Guru Profesional". Bandung : PT. Remaja Rosdakarya

10. M. Jainuri, 2010. Pengaruh Sikap Dan Tingkat IntelegensiTerhadap Prestasi Belajar Matematika SiswaKelas li Smk Tri Bhakti BangkoTahun Pelajaran 2009/2010 
11. Mathews, 2005, "An Introduction to Particle swarm optimization", Department of Computer Science, IDAHO U.S.A

12. Nazeer K, A. Abdul and Sebastian M.P, 2009, "Improving the Accuracy and Efficiency of the K-MeansClustering Algorithm", Proceeding of the World Congress on Engineering, 1:308312.

13. Purwanto, Ngalim, 1996. "Psikologi Pendidikan”. Bandung : PT. Remaja Rosdakarya

14. Purwanto, Ngalim, 2008. "Prinsip-Prinsip dan Teknik Evaluasi Pengajaran".Bandung : PT. Remaja Rosdakarya

15. Pritesh Vora, Bhavesh Oza, 2013, "A Suvey on K-Mean Clustering and Particle Swarm Optimization", International Journal of Science and Modern Engineering (IJISME), ISSN: 2319-6386, Vol-1, Issue 3
16. Panchal VK, Kundra H, Kaur J, 2009, "Comparative study of particle swarm optimization based unsupervised clustering techniques", International Jurnal of Computer Science andNetwork Security, 9(10):132 \pm 140.

17. Slameto, 2003. "Belajar dan Faktor-Faktor yang Mempengaruhinya". Jakarta : PT. Rineka Cipta

18. Xiaohui Cui, Thomas E. Potok, 2005,"Document Clustering Analysis Based on Hybrid PSO+K-Means Algorithm"

19. Ujjwal Maulik, Sanghamitra Bandyopadhyay, 2000,"Genetic algorithm-based clustering technique", The Journal of the Pattern Recognation Society 33 (2000) 1455-1465, Elsevier

20. Van der Merwe DW, Engelbrect AP, 2003, "Data clustering using Perticle Swarm Optimization", University of Pretoria, IEEE 07803-7804-0/03/417.00, hlm 215-220 